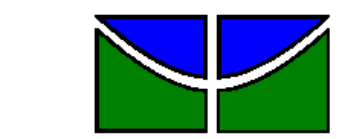

Universidade de Brasília

Faculdade de Economia, Administração, Contabilidade e Ciências da Informação e Documentação

RENATA RIBEIRO NAVEGA CRUZ

\title{
Análise da Motivação dos Empreendedores no Novo Paradigma do Século 21: um estudo de caso com empreendedores do primeiro, segundo e terceiro setor de Brasília.
}


Universidade de Brasília

Faculdade de Economia, Administração, Contabilidade e Ciências da Informação e Documentação

\section{Análise da Motivação dos Empreendedores no Novo Paradigma do Século 21: um estudo de caso com empreendedores do primeiro, segundo e terceiro setor de Brasília.}

\footnotetext{
Projeto apresentado ao Departamento de Administração como requisito parcial à obtenção do título de Bacharel em Administração.
}

Professor Orientador: Msc. Walter Eustáquio Ribeiro

$$
\text { Brasília - DF }
$$

Novembro / 2009 
Navega, Renata.

Análise da motivação dos empreendedores do novo paradigma do Século 21: um estudo de caso com empreendedores do primeiro, segundo e terceiro setor de Brasília. / Renata Navega - Brasília, 2009.

54 f. : il.

Monografia (bacharelado) - Universidade de Brasília, Departamento de Administração, 2009.

Orientador: Prof. Walter Eustáquio Ribeiro, Departamento de Administração.

1. O novo paradigma dos negócios no Século 21. 2. Empreendedorismo para o alcance da sustentabilidade. 3.Teoria Contingencial da Motivação Humana. I. Título. 


\section{Análise da Motivação dos Empreendedores no Novo Paradigma do Século 21: um estudo de caso com empreendedores do primeiro, segundo e terceiro setor de Brasília.}

A Comissão Examinadora, abaixo identificada, aprova o Trabalho de Conclusão do Curso de Administração da Universidade de Brasília da aluna

\section{Renata Ribeiro Navega Cruz}

Msc. Walter Eustáquio Ribeiro

Professor-Orientador

PhD. Antônio Júnior Professor - Examinador
PhD. Alexandre Bessa

Professor - Examinador 
À Grande Mãe, geradora e ceifadora da vida. Aquela que amorosamente nutriu minha alma com o Entusiasmo, abençoou minha Visão e me concedeu a Confiança para içar velas e navegar por um Novo Mundo.

A todos os seres humanos que caminham sobre essa Terra com a coragem de empreender um Novo Mundo. 


\section{AGRADECIMENTOS}

Agradeço à minha família de Mestras e Mestres grandiosos que teceram o fio da sabedoria ao longo das gerações e me transmitiram a sede de Infinito e a paixão pelo Servir.

Agradeço àqueles que se doaram para esse estudo e por serem a inspiração desse Trabalho:

À Mônica Passarinho, por ser uma referência do Cuidado e do Feminino na construção do Novo Mundo;

Ao Sérgio Pamplona, pela sua ética e humildade que revelam a grandeza de seu Espírito;

À disciplina da Atleta e a doação da Educadora que integradas se traduzem na realização do Serviço da Kika;

Ao Eduardo Weaver, pela sua paz de espírito capaz de falar a Verdade ao coração de todos os seres;

E à Regina Fittipaldi, por me mostrar atentamente o fluir da gestação e do parto de uma nova humanidade. 
“O que for a profundeza do teu ser, assim será teu desejo.

O que for o teu desejo, assim será tua vontade.

O que for a tua vontade, assim serão teus atos.

O que forem teus atos, assim será teu destino!”

- Brihadaranyaka Upanishad IV, 4.5 


\section{RESUMO}

Esta pesquisa tem como objetivo analisar a motivação dos empreendedores que promovem o alcance da sustentabilidade, contextualizados pelo novo paradigma dos negócios do Século 21. Para isso, este estudo foi realizado por meio de uma pesquisa qualitativa com roteiro semi estruturado, na qual foram entrevistados empreendedores do primeiro, segundo e terceiro setor de Brasília. A abordagem teórica da Motivação adotada foi a Teoria Contingencial de Victor Vroom, por meio da qual foram abordados aspectos relativos à valência, instrumentalidade e expectativa. Entre os resultados obtidos com a pesquisa, estão: a descrição dos elementos que compõe o perfil de motivação dos empreendedores que orientam sua atuação para o alcance da sustentabilidade; atributos co-relacionados à trajetória de vida e as escolhas pela atuação pró-sustentabilidade; e por fim, questionamentos norteadores para futuras pesquisas que envolvam o tema. A partir da abordagem introduzida por Vroom, foram observados no campo da valência um elevado grau de valoração e atração em relação ao trabalho que desempenham, apresentando alta determinação para o atingimento de seus resultados almejados. Quanto à instrumentalidade, entretanto, os empreendedores apresentam dificuldade em integrar conhecimento e experiência em gestão de negócios, e planejamentos pessoal e profissional para obtenção dos resultados e para manutenção da motivação a longo prazo. Por fim, em relação ao fator expectativa, os empreendedores são caracterizados pela integração da conduta na vida pessoal e profissional sendo apresentados como indivíduos comprometidos em atuar no mundo do trabalho de acordo com o que esperam ver realizado no mundo em que vivem. Esta pesquisa concluiu que há uma carência de pesquisas que integrem os estudos de motivação e o universo de empreendedores que promovem o alcance da sustentabilidade. Destaca-se ainda, a carência de conhecimento e experiência em gestão de negócios existente entre esses empreendedores, orientando-se para uma necessária integração entre o campo socioambiental e o campo empreendedor. Infere-se por meio desta pesquisa que o aumento da atuação mais consciente em relação ao meio ambiente e a sociedade é uma tendência dos empreendedores do Século 21, protagonistas de um novo paradigma onde a visão de futuro e a consciência socioambiental superam a busca pelo lucro e desenvolvimento econômico, promovendo a cidadania no mundo dos negócios em primeiro plano.
1. Sustentabilidade
2. Empreendedorismo
3. Motivação 


\section{LISTA DE ILUSTRAÇÕES}

Figura 1 - Pirâmide de Maslow............................................................................................... 31

Figura 2 - Os três fatores da Teoria de Vroom ........................................................................33 


\section{LISTA DE QUADROS}

Quadro 1 - Trechos das entrevistas ........................................................ 42 


\section{LISTA DE ABREVIAÇÕES}

CEBDS - Conselho Empresarial Brasileiro de Desenvolvimento Sustentável CEPAA - Council on Economic Priorities Accreditation Agency

CMMAD - Comissão Mundial sobre o Meio Ambiente e Desenvolvimento

IPCC - Painel Intergovernamental de Mudanças Climáticas

IPEA - Instituto de Pesquisa Econômica Aplicada

ISSO - International Organization for Standardization

ONU - Organização das Nações Unidas

SA - Social Accountability

SEBRAE - Serviço de Apoio às Micro e Pequenas Empresas

TR - Tríplice Resultado 


\section{SUMÁRIO}

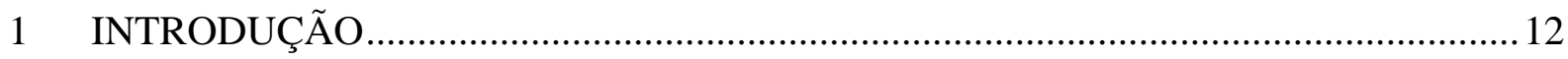

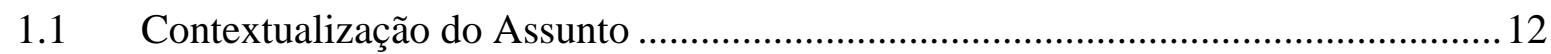

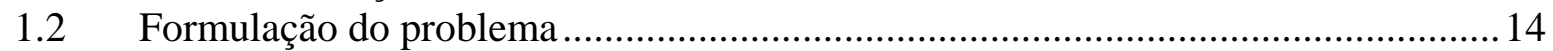

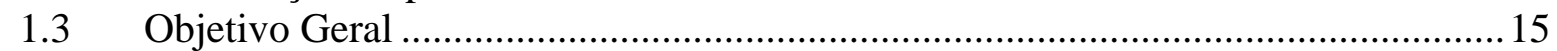

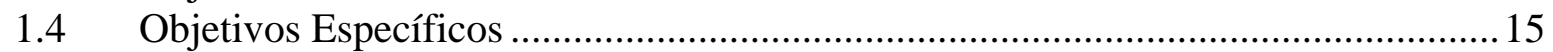

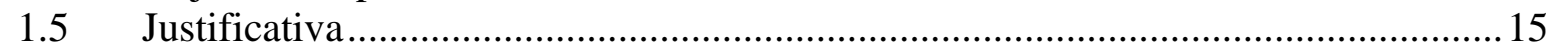

1.6 Métodos e Técnicas de Pesquisa: .........................................................................16

1.7 Estrutura e Organização da Monografia .....................................................................16

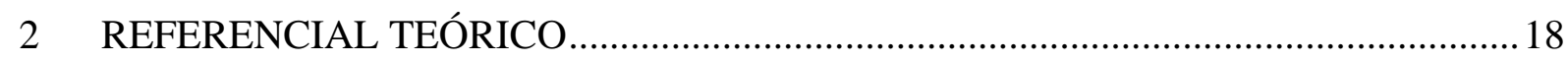

2.1 O Novo Paradigma do Século 21 ...................................................................18

2.1.1 Do Paradigma Analítico à Visão Holística....................................................18

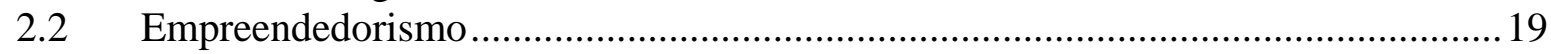

2.2.1 Desenvolvimento Histórico do Conceito.............................................................19

2.2.2 Empreendedorismo Sustentável ......................................................................22

2.3 Responsabilidade Social .....................................................................................2

2.3.1 Um breve histórico sobre Responsabilidade Social ...........................................23

2.3.2 Desenvolvimento conceitual de Responsabilidade Social....................................24

2.3.3 Responsabilidade Social no Mundo e no Brasil .....................................................26

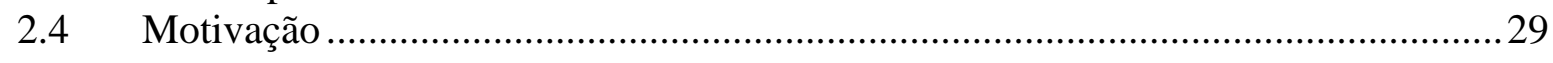

2.4.1 Desenvolvimento conceitual de motivação ........................................................29

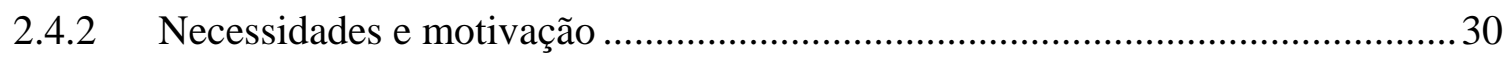

2.4.3 A Teoria Contingencial da Motivação ………………………………………....33

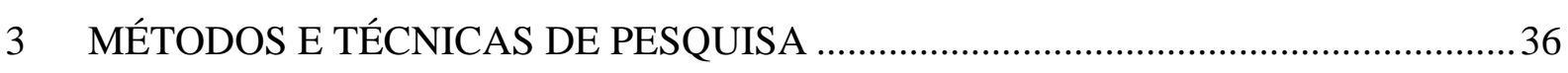

3.1 Tipo e descrição geral da pesquisa ...........................................................................36

3.2 Caracterização da organização, setor ou área ..............................................................36

3.3 Participantes do estudo .............................................................................................

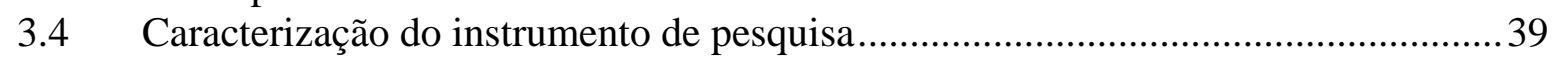

3.5 Procedimentos de coleta e de análise de dados ....................................................... 40

4 RESULTADOS E DISCUSSÃO ……………………....................................... 41

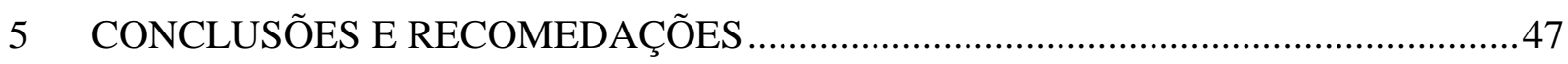

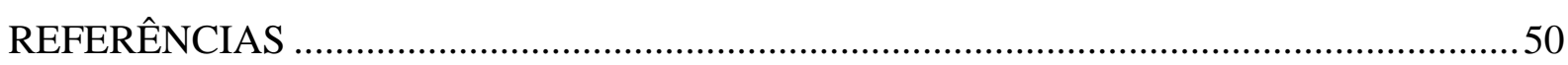

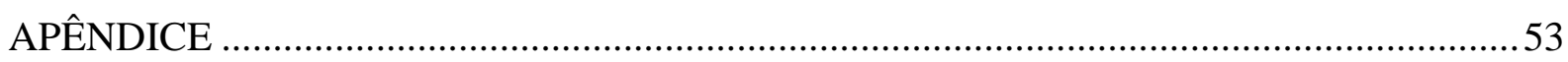

Apêndice A - Roteiro da Entrevista .....................................................................................53 


\title{
1 INTRODUÇÃO
}

\subsection{Contextualização do Assunto}

\begin{abstract}
Em função de um paradigma materialista e racionalista, estamos divorciados de nossa alma profunda, que não tem lugar nas escolas, nas empresas e espaços institucionais. No nosso contexto normótico, uma pessoa pode chegar a ser um PhD, um pós-doutor, sendo um analfabeto emocional, um bárbaro da subjetividade, um ignorante da alma. (CREMA, 2001, p.40)
\end{abstract}

Quer falemos de câncer, criminalidade, poluição, energia nuclear, inflação ou escassez de energia, a dinâmica subjacente a esses problemas é a mesma. (CAPRA, 1982).

A aurora do Século 21 ilumina um cenário de profundas transformações na cultura humana. O colapso do velho paradigma apresenta ao mundo pós-moderno os sintomas de que a atual estrutura política econômica, empresarial e social não é, em termos gerais, coerente com o desenvolvimento global viável de longo prazo. Adoecem os sistemas financeiros internacionais, adoecem as fontes de recursos naturais e adoecem por fim, os indivíduos. Afinal, as tentativas paliativas de manutenção de um sistema caduco não mais parecem surtir efeito e é chegada a hora em que a era industrial do Ocidente, a insaciável sede pelo progresso material, as crenças convencionais do método científico, e a cultura da satisfação à curto prazo não mais fazem calar os anseios humanos por um mundo mais sustentável. Vem nascendo uma mudança profunda no pensamento, percepção e valores que está transformando a visão humana da realidade para um novo paradigma. Paradigma vem da palavra greao paradeigma, que significa padrão.

Para compreender o nascente paradigma é preciso aceitar a importante tarefa de ouvir os alarmantes dilemas e problemas da atual política econômica internacional, assumir as agressões ambientais praticadas sob o jugo do desenvolvimento econômico concentrador de renda, e reconhecer o caminho insustentável que fora adotado pelas lideranças organizacionais nos últimos séculos. Em outras palavras, reconhecer onde se encontra para então olhar para onde deseja chegar. Como dito por Crema (2001), é preciso transcender o paradigma pós-moderno de desequilíbrios e determinismos através de uma nova consciência holística em curso com um enfoque transdisciplinar, que concilie a existência humana com a essência humana, o quantitativo com o qualitativo, o analítico com o sintético, a razão com o coração, a ciência com a consciência. Emancipando os indivíduos a assumirem seu papel na 
construção do Humanismo, praticando o que até o final do segundo milênio se estabeleceu como uma idéia.

É nesse contexto que protagonistas da transição para o novo paradigma têm atuado em diversos ambientes assumindo a importante missão de construir pontes para uma nova visão da realidade, tornando possível a percepção de meios mais sustentáveis em ser e estar no mundo social e organizacional. Esses pioneiros empreendedores são a manifestação de que “ao término de um período de decadência sobrevém o ponto de mutação. A luz poderosa que fora banida ressurge. Há movimento, mas este não é gerado pela força... o movimento é natural, surge espontaneamente. Por essa razão, a transformação do antigo torna-se fácil.” I Ching, o Livro das Mutações da tradição chinesa (apud CAPRA, 1982).

Harman (1994) tem sido, há anos o prócer da ideologia do novo paradigma e uma grande força criativa em sua disseminação. Em seu livro Uma Total Mudança de Mentalidade, publicado em 1994, Harman apresenta os antigos fatores que contribuíram para a atual situação do mundo contemporâneo, apresentando um retrospecto a partir da revolução modernizadora do pensamento do século XVII que deu origem à Era Industrial moderna do Ocidente. Segundo Harman (1994), entre os temas persistentes do velho paradigma estão: a crença de que o método científico é a única abordagem válida do conhecimento; o ilimitado progresso industrial material a ser alcançado através do crescimento econômico e tecnológico; a industrialização dos padrões de vida; e por fim a predominância do pragmatismo da satisfação dos desejos acima das tradições e coletividades.

Corroborando com essa visão, Capra (1982), em seu livro O Ponto de Mutação, acrescenta à visão de Harman a respeito dos fatores que contribuíram para o atual estágio do velho paradigma, a concepção da vida em sociedade como uma luta competitiva pela existência. Esse último aspecto introduzido por Capra (1982) provoca uma discussão acerca da dificuldade dos indivíduos em desenvolverem sistemas sustentáveis, uma vez que não se familiarizam com princípios fundamentais da sustentabilidade como a cooperação e a interdependência das partes para o equilíbrio do todo.

Com a transformação pela qual a sociedade vem passando, a população espera um novo comportamento das organizações e de suas lideranças. Comportamento este que vai além das obrigações da organização com seus consumidores, mas também com a sociedade e o ambiente no qual ela está inserida, atingindo todos seus stakeholders. Drucker (1994) ao contestar o postulado de que as empresas privadas não têm outra responsabilidade, senão a de gerar lucro esclarece que, 
Do ponto de vista ambiental, uma sociedade baseada exclusivamente nas relações de consumo é insustentável, pois provoca um grande aumento da extração de recursos naturais e despejo de resíduos, comprometendo o ciclo natural do meio ambiente, que não consegue se regenerar na mesma velocidade com a qual é degradado. A tomada de consciência quanto aos efeitos do acelerado consumo tem se intensificado a partir da década de 1980, considerando a interligação das diferentes crises ambientais, sociais e planetária, como descreve Capra:

\footnotetext{
"A deterioração do nosso meio ambiente natural tem sido acompanhada de um correspondente aumento nos problemas de saúde dos indivíduos. Enquanto as doenças nutricionais e infecciosas são as maiores responsáveis pela morte no Terceiro Mundo, os países industrializados são flagelados pelas 'doenças da civilização’, sobretudo as enfermidades cardíacas, o câncer e o derrame. Quanto ao aspecto psicológico, a depressão grave, a esquizofrenia e outros distúrbios de comportamento, parecem brotar de uma deterioração paralela de nosso meio ambiente social. Existem numerosos sinais de desintegração social, incluindo o recrudescimento de crimes violentos, acidentes e suicídios; o aumento do alcoolismo e consumo de drogas; e um número crescente de crianças com deficiência de aprendizagem e distúrbios de comportamento.”

(...)

"A par dessas patologias sociais, temos presenciado anomalias econômicas que parecem confundir nossos principais economistas e políticos. Inflação galopante, desemprego maciço e uma distribuição grosseiramente desigual da renda e da riqueza passaram a ser características estruturais da maioria das grandes economias nacionais. A consternação e o desalento resultantes disso são agravados pela percepção de que a energia e nossos recursos naturais - os ingredientes básicos de toda a atividade industrial - estão sendo rapidamente exauridos.” (CAPRA, 1987, p. 21-22).
}

O atual momento da humanidade é o de transição para uma realidade mais sustentável. A sociedade está presenciando o resgate dos valores de comunidade como sendo a inteligência necessária para enfrentar a turbulenta transição do velho para o novo paradigma. Segundo Aktouf (2004), ao acelerarem-se os processos econômicos de geração de riqueza, ocorre a espoliação cada vez mais rapidamente das riquezas do planeta e são privadas as gerações futuras de uma vida com qualidade na Terra. Existe um consumo dos recursos naturais que vão além das necessidades básicas humanas. Resumindo, pode-se dizer que “o consumo é necessário à vida; o consumismo depreda a vida”. (TRIGUEIRO, 2005, p.295)

\subsection{Formulação do problema}

O que tem sido importante para a motivação dos empreendedores da sustentabilidade no novo paradigma do Século 21? Essa questão define o olhar específico dessa pesquisa que inicia um diálogo com o universo do empreendedor do novo paradigma do século 21 através da análise dos elementos da sua motivação. 
Muito tem sido discutido acerca das teorias da motivação, e também acerca do empreendedorismo social. Contudo, há ainda um campo vasto de possibilidades pouco conhecido sobre estudos que aprofundem a compreensão da motivação dos empreendedores que se lançam nesse cenário de atuações que promovam uma nova realidade social e organizacional.

\subsection{Objetivo Geral}

O objetivo geral deste estudo é analisar a motivação dos empreendedores da sustentabilidade do novo paradigma do Século 21. Dessa forma, espera-se obter elementos significativos para o aprofundamento de futuras pesquisas do tema.

\subsection{Objetivos Específicos}

Esta pesquisa tem como objetivos específicos:

- Identificar os elementos fundamentais da motivação dos empreendedores entrevistados a partir da abordagem teórica definida.

- Apresentar os desafios à motivação relativos ao universo de empreendedores que promovem o alcance da sustentabilidade.

- Caracterizar a motivação dos empreendedores do novo paradigma do século 21 a partir da correlação dos elementos motivacionais identificados com os entrevistados.

\subsection{Justificativa}

A motivação desta pesquisa nasce a partir do encontro com empreendedores que tem resignificado a atuação empreendedora, construindo novas trilhas de possibilidades para um mundo mais sustentável. Esse estudo considera importante compreender o contexto do novo paradigma dos negócios a partir de uma reestruturação coletiva da realidade que vêm surgindo no século 21. Com um olhar especifico sobre os empreendedores que promovem o alcance da sustentabilidade, essa pesquisa observa a motivação desse grupo de indivíduos a partir da abordagem teórica da Teoria Contingencial de Victor Vroom.

Diante do colapso do antigo paradigma citado acima, esse tema possui elevada importância em todos os cenários de estudos sobre gestão e empreendedorismo no século 21 por aprofundar um diálogo entre as teorias de motivação e os empreendedores do novo paradigma. 
Muito tem sido discutido acerca das teorias da motivação, e também acerca do empreendedorismo social. Contudo, há ainda um campo vasto de possibilidades pouco conhecido sobre estudos que aprofundem a compreensão da motivação dos empreendedores que se lançam nesse cenário de atuações que promovam uma nova realidade social e organizacional.

\subsection{Métodos e Técnicas de Pesquisa:}

O estudo foi realizado por meio de uma pesquisa qualitativa com roteiro semi estruturado, na qual foram entrevistados cinco empreendedores do primeiro, segundo e terceiro setor de Brasília. A abordagem teórica da Motivação adotada foi a Teoria Contingencial de Victor Vroom, por meio da qual foram abordados aspectos relativos à valência, instrumentalidade e expectativa.

As entrevistas foram realizadas presencialmente os empreendedores em que se buscou analisar ambientes distintos a fim de enriquecer a análise dos elementos da motivação por meio da comparação dos setores e das áreas de atuação.

O instrumento utilizado para coleta de dados foi construído a partir da abordagem teórica da motivação adotada que foi a Teoria Contingencial de Victor Vroom. Dessa forma, foi construído um roteiro semi estruturado no qual foram abordados os três fatores inerentes à motivação, de acordo com Vroom (1995), são eles: o grau de valência, a consciência da instrumentalidade e a expectativa de realização.

As entrevistas foram gravadas e transcritas para facilitar a coleta e a análise dos dados.

O conteúdo das respostas foi classificado de acordo com os três fatores da abordagem teórica definida. Assim, a análise dos dados empregados consistiu na identificação dos elementos da motivação dos empreendedores, suas dificuldades e desafios em manter a motivação e as expectativas de realização do trabalho que empreendem.

\subsection{Estrutura e Organização da Monografia}

Esta pesquisa está organizada em seis divisões, levando em consideração essa introdução. No segundo capítulo é apresentado o referencial teórico no qual, a partir da revisão bibliográfica, é conceituado o empreendedorismo na perspectiva sustentável, e 
aplicação da abordagem teórica da motivação que foi adotada, a Teoria Contingencial desenvolvida por Victor Vroom. No terceiro capítulo, é tratada a metodologia que se utilizou para a elaboração do artigo e da pesquisa de campo. Encontra-se no quarto capítulo os resultados alcançados e posteriormente, no quinto capítulo a conclusão do estudo. Por fim, o sexto capítulo informa todas as obras utilizadas para a elaboração deste estudo. 


\section{REFERENCIAL TEÓRICO}

\subsection{O Novo Paradigma do Século 21}

\subsubsection{Do Paradigma Analítico à Visão Holística}

No Ocidente, o método analítico foi essencialmente concebido no discurso filosófico de René Descartes (1596-1650), considerado o pai do racionalismo moderno. O pensamento cartesiano foi construído a partir do método analítico newtoniano que implica em primeiro lugar no processo de decomposição de um objeto em seus componentes, e em segundo, na relação de como o efeito depende de respectivas causas. Segundo Crema (1995), o postulado subjacente ao paradigma cartesiano-newtoniano é que os fenômenos são causados e redutíveis aos seus elementos: é redutível - causal e o encantamento de Descartes pelas máquinas influenciou profundamente o a sua visão de homem.

Com a origem do mecanicismo da ciência e a ênfase empírica, apoiada na causalidade sempre buscando regularidades, tal paradigma se configurou determinista e com a pretensão de desempenhar uma função explicativa da natureza. Alguns séculos depois, o enfoque analítico foi aplicado à ciência psíquica pelo psiquiatra Sigmund Freud (1856 1939), criador da psicanálise. Com base nos pressupostos científicos de sua época Freud adentrou o mundo da psique com o enfoque analítico com a mesma pretensão explicativa, vide o ditado popular “Freud Explica!”. "Preso desde o início ao mal-entendido cientificista, Freud sucumbe a um objetivismo que retorna, sem qualquer mediação, do estágio de autoreflexão ao positivismo da época e assume por isso mesmo, uma forma particularmente áspera”, afirma o filósofo alemão Habermas (1987) discorrendo sobre o “auto-equívoco cientificista da metapsicologia freudiana”.

A rudimentar visão mecanicista do homem revela que o método analítico tem sua comprovada utilidade e eficácia: analisar para controlar, seguindo o antigo postulado estratégico: dividir para reinar. Segundo Crema (1995) profundo pesquisador da visão holística não é de se estranha que a ciência ocidental, analítica por excelência, tenha se centrado na frenética busca de controle das variáveis e dos eventos. Caracteriza-se pelo aspecto quantitativo, perseguindo o ideal da codificação matemática. Tem como meta ideal a objetividade e isenção valorativa, excluindo a subjetividade de seu manipulador. 
Entretanto, o método analítico esbarra na dimensão essencial do homem. Ele fracassa diante daquilo que os antigos denominavam de Mistério. Não há bisturi para dissecar o Holos, reduzindo-o a meras engrenagens e explicações reducionistas. Um novo caminho torna-se indispensável para o investigador do fenômeno humano. O método sintético delineou-se no final do século XIX e início do século passado, como uma reação da fragmentação exarcebada pela síndrome do analicismo, como nos traz Crema (1995). Sua tendência e inclusora, ampliadora e de integração. Seu enfoque é orgânico, resgatando os ritmos vitais e sabedoria ancestral. Fundamentada nas funções psíquicas do sentimento e da intuição. Assume um caráter consciencial e subjetivo, a intersubjetividade e os valores.

A visão holística tem como chave de compreensão o entendimento de que o enfoque analítico e o sintético não são antagônicos, e sim complementares. A parcialização analítica é um processo necessário e saudável desde que seguida por uma integração sintética que vincula e restaura. Como Crema (1995) enuncia "a análise decompositora precisa ser sucedida - e não substituída - por uma síntese unificadora”.

\subsection{Empreendedorismo}

\subsubsection{Desenvolvimento Histórico do Conceito}

Muito se fala a respeito do empreendedorismo e pouco se conhece acerca do seu conceito e histórico cultural. Segundo Souza (2004), os termos empreendedor e empresa têm sua origem em torno do século XV, na França. A empresa como categoria da vida econômica e social, segundo Segrestin (1996), é um fato histórico inserido recentemente no desenvolvimento da civilização.

Nos séculos XVI e XVII com a abertura econômica do mundo, através das grandes navegações, o regime econômico e rural deu lugar ao modelo mercantilista, que proferia a máxima "É fundamental que a moeda circule", ela deve intermediar todas as trocas (VÉRIN, 1982, p. 97). Com o surgimento da lei do comércio, as novas formas de organização de oferta e demanda anunciam a necessidade de um articulador entre o antigo sistema e o novo. Esse importante papel de fazer circular e multiplicar a riqueza era desempenhado por um novo ator, o negociante, que se preocupava com o risco do mercado e com o processo de venda de toda uma região. 
As pessoas de negócio constituíam grupos heterogêneos, indo do simples mercador ao negociante, do fabricante ao proprietário. Segundo Segrestin (2006), o sistema mercantilista não era senão um “enxerto” em uma rede corporativa local, na qual era quase impossível diferenciar as estruturas sociais das econômicas. Essa progressiva transformação do sistema de produção, conseqüentemente desencadeou a transformação da ordem social.

Nesse contexto revolucionário, fora cunhado uma nova terminologia para as constantes transformações que se realizavam na sociedade. Empreender representa mobilizar meios para fins, de uma maneira distinta daquela tradicionalmente utilizada pela sociedade, ou seja, empreender significa renovar. Segundo Schumacher (1982), o empreendedor surge emprestando dinheiro, comprando para estocar, envolvendo-se em negócios sem garantias quanto aos resultados. Observa-se também que os agentes de transformação conhecidos como empreendedores eram tidos como revolucionários, conforme diz Vérin (1982, p.171) “o ato de empreender era, por natureza, um ato subversivo da ordem predominante”.

A empresa por sua vez representou uma ruptura das redes sociais. Conforme diz Vérin (1982), as redes de produção estavam inseridas nas redes sociais, com a entrada das empresas aconteceu uma ruptura dessa interação. E em decorrência da fragmentação da produção na sociedade, o empreendedor passa a inserir-se no sistema de corporações que delimita a atuação empreendedora à produção. Finalmente, no século XVIII, a empresa adquire sua significação moderna: sistema de produção capitalista e estabelecimento de produção, no qual a atividade econômica está separada da familiar. (SEGRESTIN, 1996, p.12).

Ao longo dos últimos séculos, as empresas conquistaram diferentes espaços na sociedade, demandando mudanças de perfis de seus empreendedores. Esse perfil é interpretado, atualmente, como o líder que se orienta, estrategicamente, em não mais controlar, mas, sim, desenvolver potencial pessoal e profissional de cada membro da organização.

Apesar do debate que se criou acerca do perfil empreendedor, algumas questões permanecem em aberto em busca de um aprofundamento teórico e vivencial. A grande dificuldade encontrada está em quais valores é necessário modificar e quais são as características do empreendedor e, ainda, o mais importante, como desenvolver competências empreendedoras para atuar em um novo mundo, regido por um novo paradigma.

Os enfoques de maior destaque nos estudos sobre empreendedorismo, por estarem sendo utilizados com maior intensidade no campo científico, são: o econômico, representado por pensadores como Schumpeter (1982), e comportamental, representado por pensadores 
como McClelland (1972). De modo geral, os economistas tendem a associar empreendedorismo com inovação, enquanto os comportamentais concentram-se nas características criativas e intuitivas dos indivíduos empreendedores.

Para Schumpeter (1982), o produto, a produção, a comercialização/distribuição, o mercado, os componentes/suprimentos e o processo da gestão organizacional são os espaços de atuação do empreendedor; espaços esses voltados para a inovação na medida em que esse autor entende o termo produto como a descoberta de um novo bem ou uma nova qualidade; produção como introdução de um novo método capaz de revolucionar o processo produtivo; e distribuição como algo capaz de promover maior aproximação dos consumidores em relação aos produtos. No que diz respeito ao mercado, Schumpeter (1982) considera o empreendedor capaz de descobrir nichos, bem como fontes de produtos e serviços. O processo de gestão volta-se para a inovação ao serem criados, pelo empreendedor, modelos de organização do negócio, que venham a assegurar sua manutenção e crescimento. Para esse autor, esses indivíduos deixam de ser empreendedores, quando deixam de inovar.

A visão comportamental do empreendedorismo teve início com Weber em sua obra A ética protestante e o espírito do capitalismo, publicada em 1904, que definiu indivíduos empreendedores como pessoas inovadoras que possuem uma importante função de liderança em um ambiente organizacional. Uma das maiores referências no campo do empreendedorismo foi McClelland (1972), que relaciona o conceito de empreendedor à necessidade de sucesso, de reconhecimento, de poder e controle. As primeiras pesquisas realizadas por este autor apresentaram, a necessidade de realização do individuo como a principal força motivadora do comportamento empreendedor. Essa força significa a vontade humana de se superar e de se distinguir, englobando um conjunto de características psicológicas e comportamentais que compreendem, entre outras, por risco calculado, iniciativa e desejo de reconhecimento.

Diversos autores tecem comentários e desenvolvem abordagens teóricas acerca do empreendedorismo. Ampliar-se para novas perspectivas é também uma característica fundamentada no perfil empreendedor. Segundo Drucker (1986), o empreendedor tende a ficar atento às contingências, como o inesperado, as incongruências, as mudanças na estrutura de um setor ou de um mercado, os novos conhecimentos para colocar em prática a mudança. Souza (2000) por sua vez, ressalta a importância do desenvolvimento de uma consciência para a formação de pessoas disseminadoras da inovação, característica básica para a formação de empreendedores. Além disso, essa autora destaca que a proatividade, a criticiade, a 
criatividade, a liderança, a visão de futuro e a independência são características fundamentais pra formação de empreendedores no mundo moderno.

\subsubsection{Empreendedorismo Sustentável}

Os relatórios do Painel Intergovernamental de Mudanças Climáticas (IPCC, em inglês), da Organização das Nações Unidas (ONU), comprovaram em 2007 que a ação do homem está colaborando para o aquecimento global e para a devastação do meio ambiente. Segundo o relatório, acredita-se que até o fim deste século a temperatura média global se eleve algo entre de $1,8^{\circ} \mathrm{C}$ a $4^{\circ} \mathrm{C}$. O aquecimento global agrava os riscos de enchentes nos centros urbanos, compromete a segurança alimentar da população e influencia diretamente o aumento de doenças conhecidas como “doenças da civilização”, como o câncer. Esse aquecimento se deve ao crescimento da população mundial e ao consumo exagerado dos recursos naturais por ela utilizados. Segundo o diretor-presidente do Instituto Akatu, Hélio Matar (2005, p.26), as pessoas estão consumindo 20\% a mais do que a Terra pode suportar.

Diante desse cenário de crises ambientais que ameaçam a sobrevivência da própria humanidade no planeta, destaca-se entre os estudos de empreendedorismo, o empreendedorismo sustentável. Conforme Lan(2005) nas últimas décadas, tanto a sofisticação dos mercados como o esgotamento dos recursos obrigaram o mundo dos negócios a reformular a forma de fazer negócio, por meio desta percebe-se que o assunto globalização evoluiu para um debate sobre o futuro da humanidade no planeta, que está ameaçado pela superprodução irresponsável de muitos empreendimentos, organizações e países. É chamado ao empreendedor a responsabilidade de pensar nos problemas sociais, ambientais e o futuro das novas gerações.

Complementando essa análise, para Savitz (2002) o movimento em busca do melhor desempenho de um empreendimento atualmente chama-se sustentabilidade, ao passo que os interesses financeiros coincidem com os interesses sociais e ambientais. Savitz (2007) afirma Sustentabilidade, na prática, pode ser encarada como a arte de fazer negócios num mundo interdependente.

A sustentabilidade pode ser compreendida a partir de três perspectivas, que ao unificadas compõem o Tríplice Resultado (TR) são elas, perspectiva da economia, perspectiva do meio ambiente e perspectiva da sociedade. Segundo Lan (2005) qualquer negócio deveria estar enfocado em buscar a realização dos objetivos sociais, ambientais e econômicos para contribuir para o desenvolvimento sustentável da sua comunidade ou região. Entretanto, é 
preciso trabalhar a mudança de consciência de muitos empreendedores que ainda se apóiam em um paradigma ultrapassado de competição e busca desenfreada pelo desenvolvimento econômico e tecnológico acima da ética do cuidado com as pessoas e com o planeta.

Essa miopia ainda presente no mundo dos negócios foi comentada por Ohmae (2005) afirmando A alta gerência é sempre lenta em apontar o dedo da responsabilidade na direção da matriz ou dela mesma. Quando as culpas globais têm sintomas locais, ele serão mais lentos ainda.

O momento de mudança paradigmática é propício para a integração da busca pelo lucro e a busca do bem comum. Para Keinter (2007) A sustentabilidade da organização depende, dentre outros fatores, da plena realização do que ela se propôs na sua missão. Ir além do mero discurso pró-sustentabilidade já se torna uma exigência dos investidores e consumidores, cada vez mais crítico em relação às ações das organizações. Savitz (2007) afirma que cada vez mais investidores estão escolhendo oportunidades de investimento com base nos antecedentes ambientais e sociais das empresas, prática denominada investimentos socialmente responsáveis.

\subsection{Responsabilidade Social}

\subsubsection{Um breve histórico sobre Responsabilidade Social}

Com a publicação do livro Responsibility of the Businessman de Howard Bowen em 1953, surgem as primeiras manifestações da idéia de inclusão de outros objetivos empresariais, além do lucro. O altruísmo da filantropia empresarial pode ser visto a partir da idéia de que a qualidade de vida da sociedade depende da preocupação dos seus integrantes com o bem-estar do próximo (MARTINS, 2001).

Após o período da Segunda Guerra Mundial, a política capitalista neoliberal ganhou proporções fazendo com que o mercado privado expandisse suas forças além de suas relações estaduais. Assim, a política do mercado privado passou a agir como regulador das ações sociais, afastando o Estado dessa que era uma de suas principais funções.

O neoliberalismo é caracterizado pela total liberdade de mercado. Ele enfatiza a iniciativa individual como a base da vida econômica e propõe um Estado responsável por apenas três funções: policiamento, administração da justiça e defesa nacional. Em 
conseqüência dessa política econômica, os números relacionados à exclusão social passaram a crescer.

Para combater essa mudança foi criado o Terceiro Setor. Este setor surgiu originalmente nos Estados Unidos a partir de atividades filantrópicas e se caracteriza pelas ações de caráter privado cuja finalidade é a geração de bens de consumo para a coletividade sem o acúmulo de excedentes econômicos (SILVA; MATOS; PICCININI, 2004).

As ações da Segunda Guerra influenciaram a população civil, acadêmicos e políticos a refletir sobre suas conseqüências que causaram grande impacto em diferentes esferas. Algumas ações, citadas a seguir, simbolizaram a manifestação dessa preocupação.

A criação da Organização das Nações Unidas (ONU), em 1945, por 51 países exemplifica esse fato. A ONU surgiu logo após a Segunda Guerra Mundial com os objetivos de manter a paz e a segurança no mundo, fomentar relações cordiais entre as nações, promover o progresso social, melhores padrões de vida e direitos humanos.

A Conferência de Estocolmo foi realizada em 1972 para discutir questões relativas à preservação do meio ambiente no mundo. Cento e treze países estiveram presentes para buscar e delinear estratégias que norteassem a preservação do meio ambiente.

Além dos encontros citados, o Convênio de Viena em 1983, a Reunião de Cúpula das Nações Unidas para o Meio Ambiente em 1992 e a assinatura do Protocolo de Kyoto em 1997 foram outros marcos que simbolizaram a manifestação dessa preocupação.

O mercado passou a ter também maior responsabilidade com as suas relações sociais. Este não poderia apenas impor produtos ou serviços à sociedade, uma vez que as empresas agora necessitavam mais dos grupos sociais do que estes delas.

Atualmente mais importante que maximizar lucro é maximizar valor. A maximização do valor ocorre, geralmente, quando a empresa amolda-se às imposições da sociedade, ou seja, passa a seguir normas que respeitem o meio ambiente, os empregados, os clientes e a comunidade. (SILVA; MATOS; PICCININI, 2004).

\subsubsection{Desenvolvimento conceitual de Responsabilidade Social}

Segundo o Instituto Ethos, o conceito de Responsabilidade Social aplicado à gestão dos negócios se traduz como um compromisso ético voltado para a criação de valores para todos os públicos com os quais a empresa se relaciona: clientes, funcionários, fornecedores, comunidade, acionistas, governo e meio ambiente.

Para NETO (2001, p. 78) a responsabilidade social das empresas concentra-se em sete vetores, os quais foram adotados pelo SEBRAE e o Instituto ETHOS, são eles: 
1. Apoio ao desenvolvimento da comunidade onde atua;

2. Preservação do meio ambiente;

3. Investimento no bem-estar dos funcionários e seus dependentes e num ambiente de trabalho agradável;

4. Comunicações transparentes;

5. Retorno aos acionistas;

6. Sinergia com parceiros; e

7. Satisfação dos clientes e dos consumidores.

Para uma gestão ser considerada socialmente responsável não basta fomentar o crescimento da empresa, com eficiência nos padrões gerenciais e alta lucratividade. É indispensável, também, a existência de consideração ao desenvolvimento dos funcionários, parceiros, ou membros de comunidades onde a empresa é atuante ou não (CAMPANHOL E BREDA, 2005).

A sociedade, após anos de luta, não permite que as empresas negligenciem as conseqüências de suas atitudes contra a comunidade em geral e, especialmente, o meioambiente, impondo, assim, uma atitude mais responsável das organizações. De acordo com a Comissão Mundial sobre o Meio Ambiente e Desenvolvimento (1988), CMMAD, o conceito de desenvolvimento sustentável pode ser entendido como aquele que atende às necessidades do presente sem comprometer as necessidades futuras.

Não há discussão sobre os fatos de que as organizações, assim como os indivíduos, têm responsabilidades sociais, à medida que seu comportamento afeta outras pessoas e, querendo elas ou não, há pessoas e grupos dispostos a cobrar essas responsabilidades por meio do ativismo político, da imprensa, da legislação e da atuação nos parlamentos. (MAXIMIANO, 2004, p. 407)

O compromisso com todos esses setores mostra uma preocupação extra da empresa que vai além de seus lucros e maximização deste. Demonstra, assim, uma face humanizada do setor privado disposta a apoiar os diversos segmentos da sociedade em outras áreas além do core work da organização.

Para Neto e Brennand (2004), a responsabilidade empresarial baseia-se na escolha e compromisso com uma causa social. Esta causa deve ter relevância expressa pelo número de pessoas afetadas, natureza do segmento populacional atingido e local de ocorrência.

Portanto, a atitude socialmente responsável da empresa revela a sua consciência social, motivada pela sua compreensão da gravidade do problema social, da importância da população-alvo deste problema e pelo desejo de transformação social da comunidade-alvo do problema. (NETO e BRENNAND, 2004, p. 11)

Mais recentemente as empresas compreendem por responsabilidade social, duas esferas em que se subdividem em responsabilidade social interna e externa. Segundo Melo 
(1999), a responsabilidade social interna busca atingir os próprios atores internos da empresa, como:

- Funcionários,

- Metodologia de trabalho;

- Cultura e missão institucional.

Na responsabilidade social externa trata-se de se atingir os atores externos que são os que, em sua grande maioria, sofrem as ações das empresas em seu ambiente.

Atualmente, as organizações investem cada vez mais em atitudes para o seu público interno. Ações voltadas para saúde, ergonomia e educação fazem parte do portfólio de produtos que as empresas oferecem para seus colaboradores. Nesse sentido, o foco dessas ações sociais é interno por promoverem antes de tudo um bem-estar dos funcionários e uma melhoria na sua forma de trabalho.

Do outro lado da esfera encontra-se a responsabilidade social externa, que focaliza seu esforço nas comunidades e o meio ambiente para, assim, construir e desenvolver valores como cidadania e desenvolvimento sustentável.

O exercício da responsabilidade social externa corresponde ao desenvolvimento de ações sociais empresariais que beneficiem a comunidade. Estas ações podem ser realizadas através de doações de produtos, equipamentos e materiais em geral, transferência de recursos em regime de parceria para órgãos públicos e ONG’s, prestação de serviços voluntários para a comunidade pelos funcionários da empresa, aplicações de recursos em atividades de preservação do meio ambiente, geração de empregos, patrocínio de projetos sociais do governo e investimentos sociais criados pela própria empresa (MELO,1999, p. 88).

Algumas instituições também tratam a responsabilidade social por meio da ética empresarial no qual tem fundamental importância por constituírem a política e caráter implícito da empresa.

Os investimentos em programas de gestão ética nas organizações surgiram com base nas demandas da sociedade, legislações, movimentos anticorrupção e de transparência internacional, tornando-se questão estratégica e fator diferencial de competitividade e de aumento da produtividade. (GARCIA, 2002, p. 57).

\subsubsection{Responsabilidade Social no Mundo e no Brasil}

Mais do que falar, os consumidores que demandam responsabilidade socioambiental parecem dispostos a agir. Estima-se que, na média mundial, um terço deles já tenha boicotado pelo menos um produto por causa de um escorregão socioambiental. Mais envolvido, ele está também atento ao que proclama a cada dia mais barulhenta publicidade verde. E também muito desconfiado do valor de suas mensagens. No Reino Unido, o Advertising Standards Authority retirou de circulação, em 2007, 19 campanhas consideradas enganosas. Por pressão 
da sociedade, o governo francês acaba de criar uma regulação para campanhas verdes visando coibir mentiras, promessas vagas, imprecisões e falsos compromissos. Nos EUA, observa-se um movimento semelhante.

No intuito de estimular a responsabilidade social empresarial, uma série de instrumentos de certificação foram criadas nos últimos anos. O apelo relacionado a esses selos ou certificados é de fácil compreensão. Num mundo cada vez mais competitivo, empresas vêem vantagens comparativas em adquirir certificações que atestem sua boa prática empresarial. A pressão por produtos e serviços socialmente corretos faz com que empresas adotem processos de reformulação interna para se adequarem às normas impostas pelas entidades certificadoras. Entre algumas das certificações estão as seguintes:

- Selo Empresa Amiga da Criança. Selo criado pela Fundação Abrinq para empresas que não utilizem mão-de-obra infantil e contribuam para a melhoria das condições de vida de crianças e adolescentes.

- ISO 14000. O ISO 14000 é apenas mais uma das certificações criadas pela International Organization for Standardization (ISO). O ISO 14000, parente do ISO 9000, dá destaque às ações ambientais da empresa merecedora da certificação.

- AA1000. O AA1000 foi criada em 1996 pelo Institute of Social and Ethical Accountability. Esta certificação de cunho social enfoca principalmente a relação da empresa com seus diversos parceiros, ou “stakeholders”. Uma de suas principais características é o cárater evolutivo já que é uma avaliação regular (anual).

- SA8000. A “Social Accountability 8000” é uma das normas internacionais mais conhecidas. Criada em 1997 pelo Council on Economic Priorities Accreditation Agency (CEPAA), o SA8000 enfoca, primordialmente, relações trabalhistas e visa assegurar que não existam ações anti-sociais ao longo da cadeia produtiva, como trabalho infantil, trabalho escravo ou discriminação.

O conceito de responsabilidade social é recente no Brasil, mas tem apresentado um aumento expressivo nas últimas duas décadas. As empresas que admitem suas responsabilidades sociais ainda são poucas, entretanto, os números mostram que são crescentes as organizações com engajamento social.

Segundo o estudo Monitor de Responsabilidade Social de 2009, realizado pela Market Analysis, quase seis entre 10 consumidores da América do Norte (56\%) e da Oceania (54\%) admitem ter recompensado uma empresa por causa de práticas socioambientais, 
comprando os seus produtos ou falando bem deles para outros. Na Europa, esse número é, em média, de quase três (29\%) em dez.

No Brasil, mais especificamente, 15,2\% dizem ter tomado decisão semelhante (8,2\% puniram, deixando de comprar). Cerca de 59,3\% nunca pensaram em punir ou premiar empresas segundo os compromissos de sustentabilidade. Fosse selecionada uma amostragem de consumidores de classe A, mais escolarizados, a proporção de “engajados" seria certamente maior, aproximando-se do padrão dos europeus.

De acordo com o IPEA, Instituto de Pesquisa Econômica Aplicada, a participação empresarial na área social aumentou para 69\% do ano 2000 a 2004, sendo assim, aproximadamente 600 mil empresas atuando voluntariamente. Em 2004, foram aplicados aproximadamente R \$ 4,7 bilhões, o que correspondia a 0,27\% do PIB brasileiro daquele ano (IPEA, 2006).

Para Gois, Santos e Costa (2004), a presença do setor privado do Brasil em ações de engajamento social surge nos primeiros anos do século XX. Contudo, é a partir da década de 70 que passa a existir um esforço sistemático em superar as ações filantrópicas e atuar em ações sociais que abrangem noções de direito e cidadania.

Percebe-se o aumento da discussão sobre responsabilidade social principalmente na década de 90. No governo Fernando Henrique Cardoso, suas políticas de privatizações de setor diminuíram a dominação do Estado nas relações econômicas do mercado privado. Assim, passou a existir um crescente interesse do setor privado nas questões sociais. Além disso, começa a crescer o interesse desse segmento em participar de investimentos sociais, como, por exemplo, a criação de instituições empresariais que difundem práticas de valores e éticas, como o Conselho Empresarial Brasileiro de Desenvolvimento Sustentável - CEBDS em 1997 e o Instituto Ethos de Empresas e Responsabilidade Social em 1998.

O Instituto Ethos se define da seguinte maneira:

O Instituto Ethos de Empresas e Responsabilidade Social é uma organização nãogovernamental criada com a missão de mobilizar, sensibilizar e ajudar as empresas a gerir seus negócios de forma socialmente responsável, tornando-as parceiras na construção de uma sociedade sustentável e justa(...)Idealizado por empresários e executivos oriundos do setor privado, o Instituto Ethos é um pólo de organização de conhecimento, troca de experiências e desenvolvimento de ferramentas que auxiliam as empresas a analisar suas práticas de gestão e aprofundar seus compromissos com a responsabilidade corporativa. (INSTITUTO ETHOS, 2008) 
A definição do Conselho Empresarial Brasileiro de Desenvolvimento Sustentável, segundo eles, é:

O Conselho Empresarial Brasileiro para o Desenvolvimento Sustentável (CEBDS)
assumiu um grande desafio: criar condições no meio empresarial e nos demais
segmentos da sociedade para que haja uma relação harmoniosa entre essas três
dimensões da sustentabilidade - econômica, social e ambiental (...) o CEBDS é uma
coalizão dos maiores e mais expressivos grupos empresariais do Brasil.
(CONSELHO EMPRESARIAL BRASILEIRO PARA O DESENVOLVIMENTO
SUSTENTÁVEL, 2008)

A responsabilidade social no Brasil pode já ser considerada um instrumento que oferece a empresa bons resultados operacionais, fôlego financeiro, melhores produtos e serviços, preços competitivos, um bom padrão de atendimento, avançada tecnologia e quadros altamente qualificativos, e, também, contribui para a melhoria da qualidade de vida desta e das próximas gerações Maia (2005).

\subsection{Motivação}

\subsubsection{Desenvolvimento conceitual de motivação}

É difícil definir exatamente o conceito de motivação, uma vez que este tem sido utilizado com diferentes sentidos. De modo geral, motivação é tudo aquilo que impulsiona a pessoa a agir de determinada forma ou, pelo menos, que dá origem a uma propensão a um comportamento específico, podendo este impulso à ação ser provocado por um estímulo externo (provindo do ambiente) ou também ser gerado internamente nos processos mentais do indovíduo. (Chiavenato, 1999).

De acordo com Borges (2004), a palavra motivação é uma derivação do latim motivus, que significa mover. Motivação pode ser definida como uma ação dirigida a objetivos, sendo auto-regulada, biológica ou cognitivamente, persistente no tempo e ativada por um conjunto de necessidades, emoções, valores, metas e expectativas. (SALANOVA; HONTANGAS; PEIRÓ, 1996, p.16).

Motivação é um processo psicológico básico de relativa complexidade, por se tratar de um fenômeno não diretamente observado e que auxilia na explicação e na compreensão das diferentes ações e escolhas individuais. Borges (2004).

Entre as teorias de Motivação encontram-se aquelas que se propõem a compreender o que ativa a motivação do indivíduo, teorias de conteúdo, e as que se preocupam como a 
motivação ocorre, teorias de processo. As teorias de processo centram-se nos processos cognitivos que afetam as decisões face ao comportamento no trabalho, ou seja, analisam os processos de pensamento através dos quais as pessoas optam por uma determinada ação entre outras. Este tipo de teoria explicita porque é que a oportunidade de obter uma promoção pode ser atraente para uma pessoa e não despertar interesse noutra. As teorias de processo são constituídas pelas teorias gerais e pelas teorias organizacionais. As teorias de processo gerais abordam a teoria de equidade de Adams e a teoria da modificação do comportamento organizacional, denominada por ModCO. As teorias de processo organizacionais abordam a teoria da definição de objetivos de Locke e Latham, a teoria da avaliação cognitiva de Deci e a teoria da espectância de Vroom (1995).

Essa pesquisa procura analisar a motivação dos empreendedores do novo paradigma por meio da abordagem teórica de Vroom. Com vistas a enriquecer o estudo, será feito um percurso teórico pela abordagem das necessidades, com ênfase na abordagem de Maslow, e pela teoria contingencial de Vroom, a fim de integrar as diferenças abordadas por esses dois pensadores. Com esse percurso teórico, espera-se ilustrar as razões pelas quais a teoria de Vroom foi a definida para orientar essa pesquisa.

\subsubsection{Necessidades e motivação}

Em pesquisas realizadas por diversos autores estudiosos da motivação humana, constatou-se que existem certas necessidades humanas fundamentais e também algumas cujas causas escapam ao próprio entendimento racional do homem. Essas causas se chamam necessidades, ou motivos, e são forças conscientes ou inconscientes que levam o indivíduo a apresentar um determinado comportamento. A motivação se refere ao comportamento, que é causado por necessidades de dentro do indivíduo e que é dirigido em direção aos objetivos que podem satisfazer suas necessidades.

De modo geral as teorias que se sustentam no conceito de necessidade partem da premissa de que há uma energia ou força que excita ou gera uma tensão interna no organismo, experimentada subjetivamente como um impulso ou desejo para agir de modo que se reduza a força deste mesmo impulso, tensão ou desejo. Segundo Borges-Andrade, Zanelli, e Bastos (2004) essas teorias estão interessadas em desvendar os aspectos individuais biológicos e psicológicos que desencadeariam um impulso ou desejo; em outras palavras, a falta ou a carência de algo a ser suprido. 
Entre as teorias de necessidade, a teoria de Maslow tem uma importância relevante no estudo da motivação humana. Em síntese, segundo Maslow, as necessidades humanas estão arranjadas em uma pirâmide de importância e de influência do comportamento humano. Na base da pirâmide estão as necessidades mais baixas e recorrentes, chamadas necessidades primárias - as necessidades fisológicas e de segurança-; enquanto no topo estão as mais sofisticadas e intelectualizadas - necessidades secundárias: sociais, de estima e de autorealização. (BORGES-ANDRADE, J.; ZANELLI, J. C.; BASTOS, 2004)

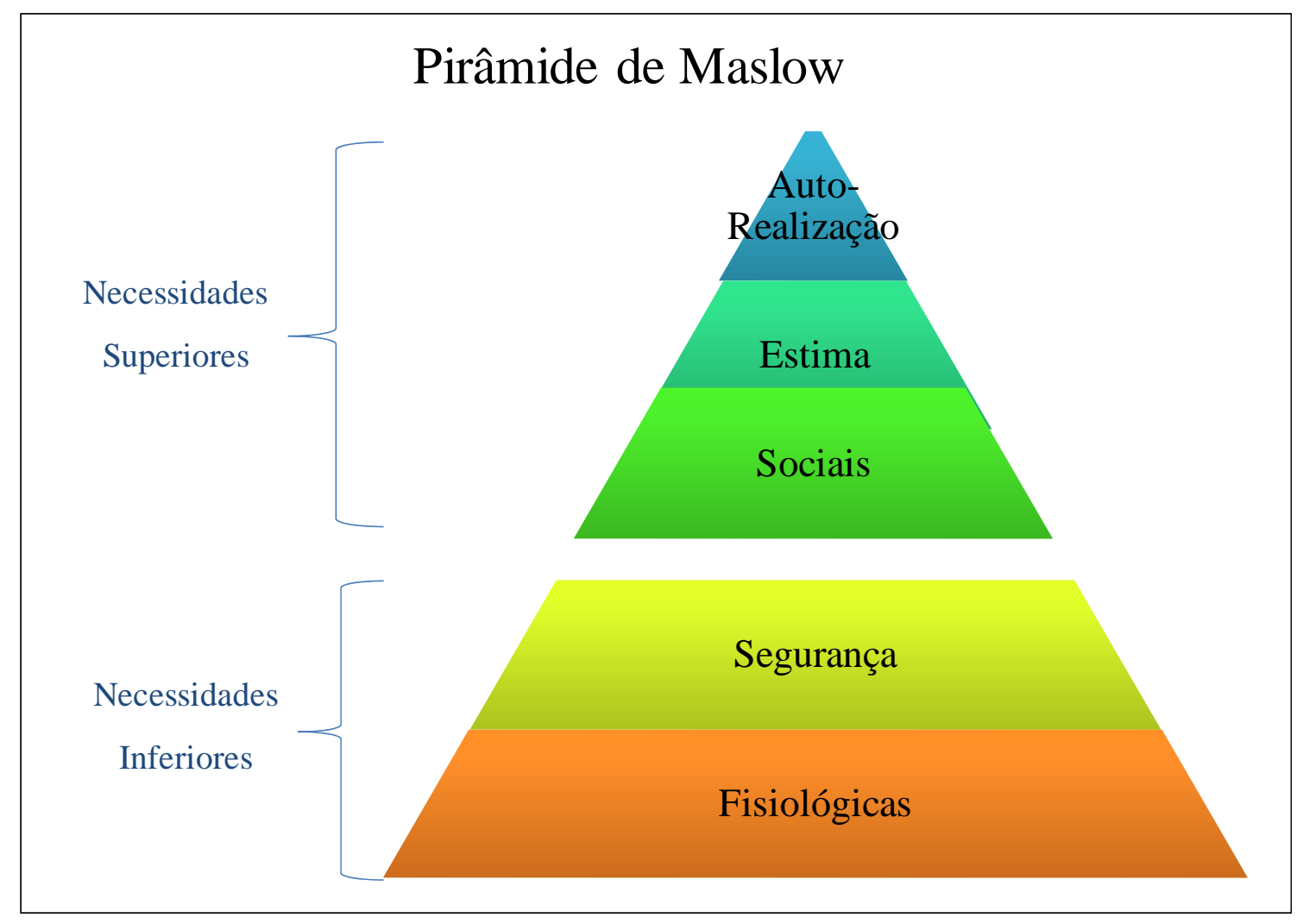

Figura 1 - Pirâmide de Maslow

Fonte: Maslow (apud BORGES-ANDRADE, J.; ZANELLI, J. C.; BASTOS, 2004)

Maslow foi responsável por organizar a compreensão das necessidades humanas e por meio desse entendimento estabeleceu a relação da motivação através da realização das necessidades.

As necessidades fisiológicas e de segurança constituem as necessidades primárias, essenciais à sobrevivência do indivíduo. São inatas e instintivas, estão relacionadas no nível mais baixo na classificação hierárquica e exigem satisfação periódica e cíclica. As principais são: alimentação, sono, atividade física, satisfação sexual, e de segurança física contra os perigos. As necessidades de segurança íntima são aquelas que levam o indivíduo a buscar sua autodefesa, a proteção contra o perigo, à ameaça ou à privação potenciais. Conduz a uma busca sem fim à tranqüilidade pessoal e à uma situação segura pra o indivíduo. 
Quando satisfeitas facilmente, deixam de ser uma motivação importante. Por outro lado, se por alguma eventualidade, elas não forem satisfeitas, passam a atuar com intensidade extremamente forte no comportamento humano.

As necessidades psicológicas, segundo Chiavenato (1999) podem ser definidas como as necessidades secundárias e exclusivas do homem. São aprendidas e adquiridas no decorrer da vida e representam um padrão mais elevado e complexo. Raramente são satisfeitas em sua plenitude por que o homem, por natureza, está sempre buscando mais satisfações dessas necessidades, que vão se desenvolvendo e se sofisticando gradativamente.

Como o homem é um ser social, ele tem necessidade de estar participando de algum empreendimento, interagindo a todo momento com meio e com outras pessoas. Entre as necessidades de participação estão a necessidade de reconhecimento do grupo a que pertence e de aprovação social. A necessidade de estima por sua vez está relacionada à condição da vida em grupo e a necessidade de dar e receber afeto.

No topo da pirâmide, Maslow elenca a necessidade de Auto-Realização que é a síntese de todas as outras necessidades podendo ser definida como o impulso que cada um tem de realizar o seu próprio potencial, de estar em contínuo autodesenvolvimento. Tratam-se de necessidades mais elevadas, produtos da educação e da cultura, podendo, portanto variar muito. Devido à busca constante do homem por novas metas, cada vez mais complexas, raramente são satisfeitas em sua plenitude, segundo a visão de Maslow.

Observa-se que a teoria de Maslow apresenta uma maior clareza sobre o universo motivacional dos indivíduos. Um aspecto relevante dessa teoria para fins de conteúdo crítico desta pesquisa é observar que Maslow compreendia a atuação do trabalho como parte da motivação do indivíduo como um todo, considerando uma serie de outros elementos importantes na composição da motivação. Observa-se ainda, que os indivíduos adotaram uma relação com o trabalho que supervaloriza o emprego de sua atenção, desequilibrando as demais necessidades como as de estima e fisiológicas.

Considerando a máxima fundamental da teoria de Maslow em que a Auto-Realização é uma síntese de todas as outras necessidades, nota-se uma questão interessante acerca do que o homem moderno vem convocando como um redesenho da relação vida pessoal e vida profissional, uma vez que a auto-realização não tem sido alcançada no presente paradigma do trabalho. 


\subsubsection{A Teoria Contingencial da Motivação}

Buscando um novo olhar sobre a motivação humana, Victor Vroom (1995) desenvolveu uma nova abordagem que identifica por um prisma contingencial os elementos da motivação. Concebida em 1964, a Teoria Contingencial defende que o processo de motivação deve ser explicado em função dos objetivos e das opções de cada indivíduo e das expectativas de atingir esses mesmos objetivos. Propondo um olhar diferente da teoria da necessidade de Maslow, a teoria de Vroom considera as diferenças individuais reconhecendo a evidência de que diferentes pessoas reagem de diferentes maneiras, conforme a situação em que estejam colocadas. Conforme dito anteriormente, esse tipo de teoria explicita porque é que a oportunidade de obter uma promoção pode ser atraente para uma pessoa e não despertar interesse noutra. Segundo Vroom (1995), existem três fatores que atuam dentro do indivíduo e influenciam o nível da sua motivação:

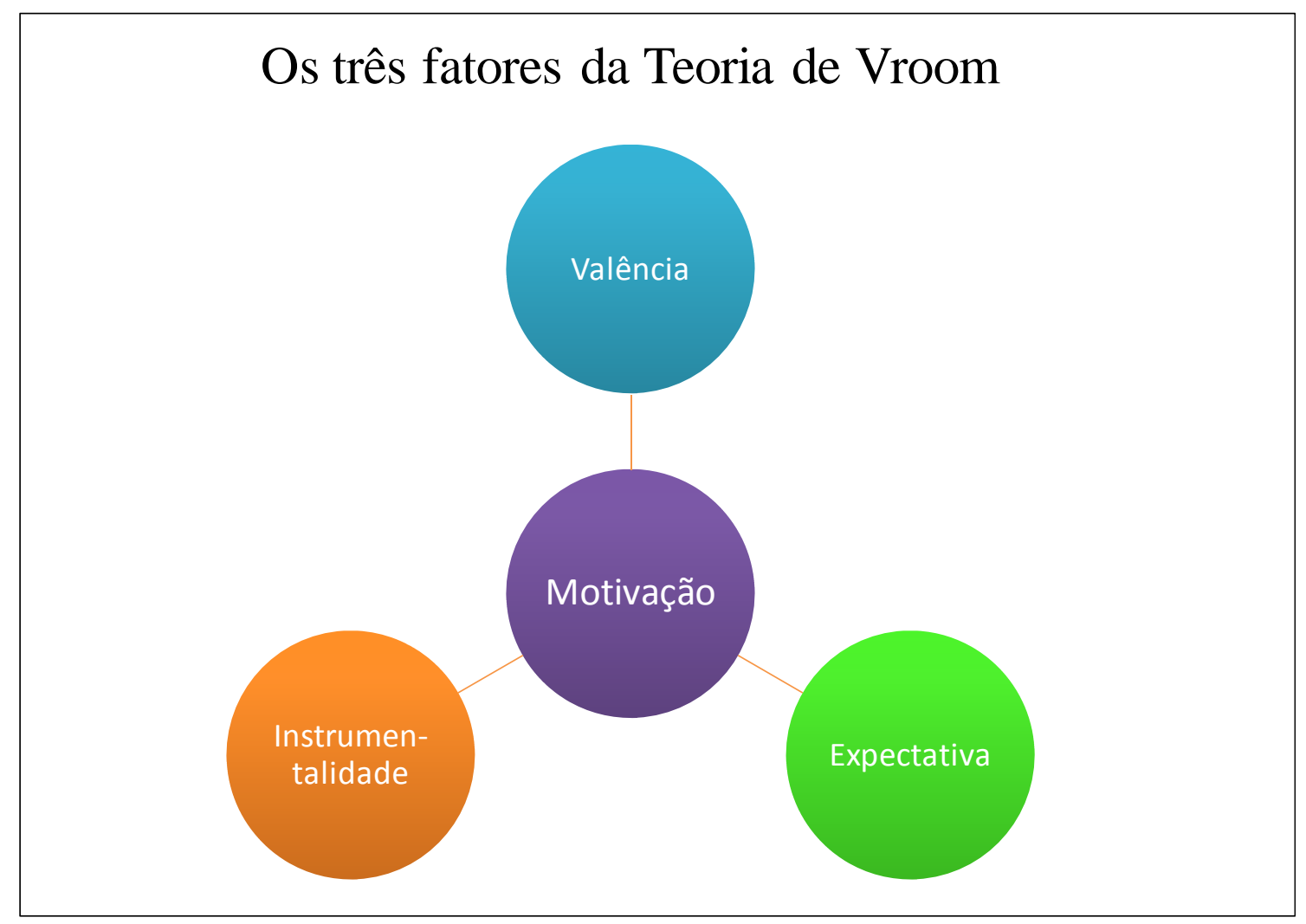

Figura 2 - Os três fatores da Teoria de Vroom

Fonte: Vroom (1995)

O primeiro fator abordado é o da valência, que significa o grau de atração do individuo pelo trabalho que ele deseja realizar. É a valência que estuda o quanto o individuo 
valoriza o que faz, e o grau de importância que atribui ao trabalho na sua própria vida. Por meio da compreensão da valência da motivação do individuo pode-se compreender que tipo de realização de fato representa uma satisfação e o que não se apresenta como valioso. Como todo estudo de motivação, as valências revestem-se de um aspecto subjetivo, uma vez que determinada realização pode não assumir importância para um indivíduo e ser muito importante para outro.

A instrumentalidade, por sua vez tem como papel identificar o grau de percepção das trilhas e dos rumos da atuação do individuo em busca da sua valência fundamental. Ao passo que o individuo identifica o caminho a percorrer, é possível compreender como o indivíduo se mantém motivado durante o processo de busca pela satisfação. Uma instrumentalidade que não tenha sido bem desenvolvida poderá desconectar o individuo do desejo de alcançar a valência. É por meio da instrumentalidade que se compreende como o individuo enfrenta desafios e se mantém no caminhar em busca da realização desejada.

O terceiro fator da teoria de Vroom centra-se na expectativa de alcançar um estado de satisfação após percorrer o longo caminho (instrumentalidade) em busca da realização almejada (valência). Em outras palavras, Vroom (1995) compreende que se um determinado esforço for exercido por um individuo que disponibilize de meios de competências para atingir o sucesso, o resultado será um desempenho bem sucedido (expectativa - esforço desempenho).

Deste modo, Vroom considera que a motivação possa ser orientada de acordo pelo equilíbrio da seguinte equação:

\section{Motivação $=\mathbf{f}($ expectativa $X$ instrumentalidade $X$ valência $)$}

O que significa que todos os termos têm que ser maiores que zero, ou seja, nenhum dos fatores pode estar ausente. Estes três elementos, segundo Vroom (1995), influenciam a motivação das pessoas no trabalho. Se um desses elementos for zero, a motivação será nula. Se todos estão presentes (expectativa alta, instrumentalidade alta, valência alta), a motivação será alta. Em suma, a Teoria de Vroom, revela que para que o indivíduo se sinta motivado é imprescindível que este se sinta capaz de atingir os objetivos pessoais delineados.

O presente percurso teórico acerca das teorias de Maslow e Vroom contextualizam o questionamento fundamental que iniciou essa pesquisa. Esse questionamento reside no campo da integração das duas teorias, ao passo que Maslow orienta as necessidades humanas ao 
caminho da auto-realização e Vroom ilumina a compreensão da subjetividade de que cada indivíduo desenvolverá uma motivação única.

Ao integrar o legado desses pensadores, essa pesquisa inicia um diálogo com a subjetividade dos empreendedores do novo paradigma do século 21, por meio da abordagem teórica de Vroom, compreendendo a motivação por uma nova atuação empreendedora que busca a auto-realização humana enunciada por Maslow. 


\section{MÉTODOS E TÉCNICAS DE PESQUISA}

O instrumento utilizado para coleta de dados foi construído a partir da abordagem teórica da motivação adotada que foi a Teoria Contingencial de Victor Vroom. Dessa forma, foi construído um roteiro semi estruturado no qual foram abordados os três fatores inerentes à motivação, de acordo com Vroom (1995), são eles: o grau de valência, a consciência da instrumentalidade e a expectativa de realização.

As entrevistas foram gravadas e transcritas para facilitar a coleta e a análise dos dados.

O conteúdo das respostas foi classificado de acordo com os três fatores da abordagem teórica definida. Assim, a análise dos dados empregados consistiu na identificação dos elementos da motivação dos empreendedores, suas dificuldades e desafios em manter a motivação e as expectativas de realização do trabalho que empreendem.

\subsection{Tipo e descrição geral da pesquisa}

Esta é uma pesquisa do tipo exploratória, pois inicia um diálogo entre o universo dos empreendedores que promovem o alcance da sustentabilidade e o estudo acadêmico da motivação, em especial, sob a perspectiva da Teoria Contingencial de Victor Vroom. A pesquisa se propõe a trazer elementos sobre a motivação dos indivíduos que se destacam no mundo dos negócios por promover sociedades mais sustentáveis.

O estudo foi realizado por meio de uma pesquisa qualitativa com dados primários coletados por meio de entrevistas com indivíduos que promovem o alcance da sustentabilidade por meio de sua atuação como empreendedores, em áreas e setores distintos da sociedade.

\subsection{Caracterização da organização, setor ou área}

As entrevistas foram realizadas presencialmente com cinco empreendedores do primeiro, segundo e terceiro setor de Brasília, em que se buscou analisar ambientes distintos a 
fim de enriquecer a análise dos elementos da motivação por meio da comparação dos setores e das áreas de atuação.

Entre as áreas de atuação dos empreendedores estão a bioarquitetura, a educação ambiental, a produção e o tratamento de resíduos orgânicos e a preservação ambiental.

Os empreendedores entrevistados se encontram no primeiro, segundo e terceiro setor, atuando por meio do Governo Federal, empresa privada, Organização Não Governamental e fundação educacional.

\subsection{Participantes do estudo}

Essa pesquisa identificou nos três setores da sociedade empreendedores que promovem a sustentabilidade por meio do seu trabalho. Foram definidos dois critérios de seleção dos participantes desse presente estudo, a saber: em primeiro lugar apresentar destaque na atuação como empreendedor pela sustentabilidade na área em que atua, e em segundo, apresentar interesse em refletir sobre os elementos da motivação que os induzem a atuar em prol da sustentabilidade na sociedade em que vivem.

A partir dos critérios descritos acima, cinco empreendedores distribuídos entre os três setores da sociedade foram convidados a participar dessa pesquisa. Todos os indivíduos selecionados atuam de forma empreendedora tendo a busca pela sustentabilidade na sociedade como propósito maior do seu trabalho. Esta singular característica os une neste estudo em que o foco incide sobre o empreendedor que está por trás do empreendimento que promove a sustentabilidade trazendo luz para a motivação desses pioneiros do novo paradigma do século 21.

A primeira entrevistada é bióloga, desenvolve projetos de educação ambiental por meio da permacultura em uma Organização Não Governamental de Brasília, onde coordena atividades na área da Ecopedagogia através de vivências educacionais em áreas protegidas do Cerrado. Além disso, criou uma marca de produtos ecológicos sob a qual elaborou diferentes linhas de produtos com o objetivo de proporcionar opções ecologicamente corretas para as pessoas, a sociedade e o meio ambiente, com o enfoque da redução do lixo nas cidades. Entre os ecoprodutos da marca, encontram-se absorventes femininos e fraldas reutilizáveis. Atualmente, a marca tem atendido demandas de Brasília, com um ponto de venda na Asa 
Norte, em outras cidades do Brasil, como Florianópolis, João Pessoa, Rio de Janeiro e Belém, e também expondo em outros países como Cuba e Argentina.

O segundo entrevistado é arquiteto, permacultor e desenvolve projetos de bioarquitetura para todo o país. Estudou na Universidade de Brasília e passou a pesquisar diferentes formas de abordar a ocupação humana no planeta que pudessem ser mais sustentáveis. É um profissional autônomo e trabalha com arquitetos associados para implementação de seus projetos. Além disso, desenvolveu trabalhos com edição de revistas na área da bioarquitetura e permacultura, empreendendo informações sobre o assunto no Brasil.

A terceira entrevistada estudou Educação Física e Pedagogia para encontrar intersecções de uma abordagem educacional que pudesse conectar o ser humano com os ambientes ao ar livre que estivessem mais próximos da Natureza. Desenvolveu uma tese nesse assunto no mestrado na Austrália, onde teve profundo contato com a permacultura e suas aplicações urbanas. Ainda na Austrália pesquisou políticas públicas que estimulam os cidadãos a praticarem a cidadania por meio da consciência ecológica, em especial quanto à separação e destinação correta dos resíduos orgânicos e inorgânicos. De volta ao Brasil abriu uma empresa de soluções para o tratamento correto dos resíduos orgânicos, que oferece kits de minhocários adaptados para casas e apartamentos para pessoas que têm a vida agitada da cidade. Além dos kits de minhocários a empresa abrange oficinas de educação ambiental para jovens, adultos e crianças. Atualmente, a empresa tem atendido a demanda de Brasília e já está prospectando clientes em outros estados como São Paulo e Santa Catarina, participando de feiras de sustentabilidade de todo o país.

O quarto entrevistado desse estudo é engenheiro eletrônico, pesquisador da teosofia, e empresário. Desenvolveu sua carreira na área de Tecnologia da Informação, na qual atuou por 25 anos. Mudou-se para Brasília há 6 anos, quando passou a integrar movimentos pró sustentabilidade, em contato com projetos de preservação do meio ambiente e ideais de uma vida mais plena e saudável. Reconheceu nos projetos da cidade a oportunidade de integrar sua filosofia de vida em atividades profissionais e fundou uma empresa que tem como atuação orientar e facilitar as demais organizações a viverem de forma mais sustentável. (metologia) Entre os clientes que possui, estão empresas, governo, OnGs e pessoas físicas. Atualmente, o empresário tem se voltado para aprofundar-se no ramo da educação ambiental, onde passou a integrar conhecimentos e experiências internacionais como Singapura e Estados Unidos na formação de educadores para o novo milênio. 
A quinta entrevistada deste estudo é arquiteta e pró-reitora de uma universidade holística da paz voltada para a formação transdisciplinar do novo paradigma do século 21, sendo também vice presidente da fundação educacional mantenedora dessa universidade, sediada em Brasília. A arquiteta integra princípios e valores ecológicos à arquitetura de uma nova cultura de paz. Desenvolve projetos voltados para sustentabilidade dos ecossitemas urbanos, e para a formação de designers de sustentabilidade, tendo como base a visão holística e transdisciplinar. Colaborando para a construção de uma educação para o novo milênio escreve livros, artigos e periódicos, palestra em diversas cidades do país, além de conduzir um programa de televisão de amplitude internacional sobre a ética do cuidado com as pessoas e com o planeta.

\subsection{Caracterização do instrumento de pesquisa}

O instrumento utilizado para coleta de dados foi construído a partir da abordagem teórica da motivação adotada que foi a Teoria Contingencial de Victor Vroom. Dessa forma, foi construído um roteiro semi estruturado no qual foram abordados os três fatores inerentes à motivação, de acordo com Vroom (1995), são eles: o grau de valência, a consciência da instrumentalidade e a expectativa de realização por meio do trabalho.

O conteúdo que se esperava obter por meio das respostas foi classificado de acordo com os três fatores da abordagem teórica definida e acrescido de um breve relato da trajetória de vida do indivíduo discorrendo acerca dos elementos que contribuíram para a escolha que definiram sua atuação pela sustentabilidade. Assim, o roteiro contemplou a identificação dos elementos da motivação dos empreendedores, suas dificuldades e desafios em manter a motivação, e por fim, as expectativas de realização do trabalho que empreendem.

A entrevista foi dividida em quatro partes principais. A primeira, na qual se o entrevistado fora convidado a compartilhar brevemente a sua trajetória de vida, abordando os principais elementos que foram importantes para a escolha do caminho voltado para sustentabilidade.

Em seguida, abordou-se a valência motivacional dos indivíduos que objetivou identificar o grau de atração do indivíduo com o trabalho que desenvolve. Abordou-se assim, elementos como as razões determinantes pelas quais sentiu-se e continua sentindo-se atraído pela atuação que desempenha. 
Na terceira parte da entrevista foram abordados elementos da instrumentalidade que teve como objetivo identificar o grau de consciência do caminho a percorrer para manter a motivação. Questões como planejamentos pessoais e profissionais, descrição dos desafios e dificuldades do caminho foram trazidas para contextualizar o individuo no processo de busca de sua auto-realização.

Por fim, na quarta parte da entrevista foram abordadas questões sobre a expectativa do indivíduo em realizar seu papel de acordo com a conduta que escolheu. Falou-se sobre o impacto das realizações alcançadas na vida pessoal e na sociedade. Abordou-se o aumento de profissionais que vem se destacando com a atuação voltada para a sustentabilidade.

As entrevistas se encerraram a partir das mensagens encorajadoras deixadas pelos entrevistados aos novos empreendedores que estão despertando para uma nova forma de atuação, mais consciente do seu papel na sociedade contemporânea.

O roteiro da entrevista foi validado por meio de pré-teste no qual foram observadas as adaptações necessárias para o melhor funcionamento das entrevistas.

\subsection{Procedimentos de coleta e de análise de dados}

A coleta de dados ocorreu por meio de entrevistas devidamente gravadas e transcritas. As entrevistas ocorreram durante os meses de outubro e novembro de 2009 na cidade de Brasília, por meio de encontros presenciais com a autora dessa pesquisa.

Em seguida os dados foram transcritos para análise em meio eletrônico na qual foram agrupadas as respostas de acordo com os fatores de motivação previstos por Vroom (1995). O roteiro da entrevista foi previamente estruturado com vistas a implementar a análise de conteúdo de acordo com a abordagem teórica definida na pesquisa.

Dessa forma, as principais análises realizadas tiveram como primeiro passo a organização das respostas em temáticas relativas a valência, instrumentalidade e expectativa. E em seguida na associação entre as respostas equivalentes a motivação do individuo, de maneira que fosse possível mapear correlações dos elementos da motivação enriquecendo a análise. 


\section{RESULTADOS E DISCUSSÃO}

A seguir são apresentados trechos relevantes das entrevistas realizadas, seguidas de análises estruturadas com base na abordagem metodológica de Victor Vroom (1995). Para melhor compreensão da abordagem no contexto deste estudo, os trechos selecionados para esta seção estão organizados de acordo com a seqüência da entrevista.

\begin{tabular}{|c|c|c|}
\hline \multirow{3}{*}{ 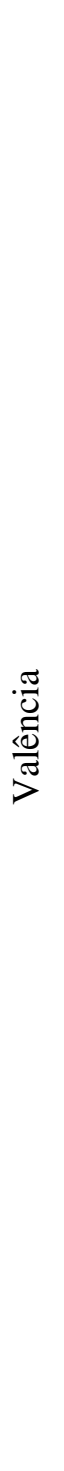 } & $\begin{array}{l}\text { 1) Quanto você valoriza sua } \\
\text { atuação profissional na sua } \\
\text { vida? }\end{array}$ & $\begin{array}{l}\text { "Não pretendo me aposentar nunca” } \\
\text { "valorizo meu trabalho } 100 \% \text {. Minha atuação no trabalho } \\
\text { significa minha razão de estar no mundo e está totalmente } \\
\text { integrada com os valores que eu acredito." } \\
\text { "meu trabalho é absolutamente integrado à minha vida. É um } \\
\text { dos caminhos mais fortes para mim em termos de } \\
\text { crescimento pessoal.” } \\
\text { "não sou uma pessoa diferente do que eu sou na minha vida } \\
\text { pessoal e do que eu sou no trabalho. Busco ser o que eu } \\
\text { acredito, por isso realizo aquilo sou." } \\
\text { "a minha vida profissional não é separada da minha vida } \\
\text { pessoal. O meu trabalho é a minha própria vida!" }\end{array}$ \\
\hline & 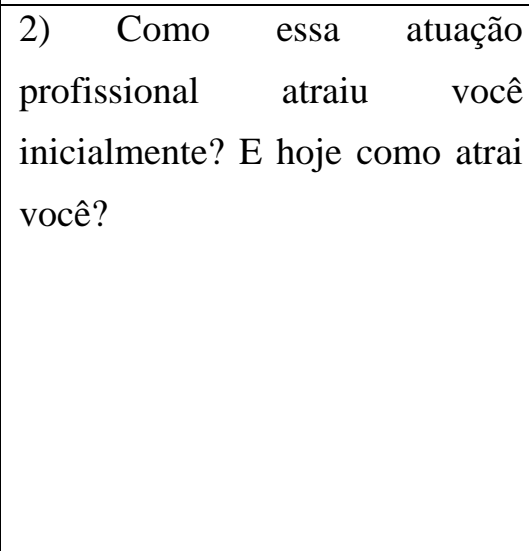 & $\begin{array}{l}\text { "a busca por uma vida mais saudável, conectada com a } \\
\text { natureza me levou a trabalhar a pedagogia com uma nova } \\
\text { abordagem. Hoje o doutorado já representa um novo desafio } \\
\text { para estudar o comportamento humano em relação à } \\
\text { sustentabilidade. Nunca me acomodei” } \\
\text { "a busca pela aprendizagem sempre impulsionou a atração } \\
\text { por novos conhecimentos. Saber que ainda tenho muito a } \\
\text { aprender me manteve motivado a atravessar longos caminhos } \\
\text { no escuro do que eu iria desenvolver.” }\end{array}$ \\
\hline & $\begin{array}{l}\text { 3) O que espera realizar } \\
\text { profissional e pessoalmente por } \\
\text { meio dessa atuação? }\end{array}$ & $\begin{array}{l}\text { "ser um diferencial pela mudança do país. Busco ampliar } \\
\text { minha atuação para alcançar uma maior dimensão social e } \\
\text { educacional brasileira." }\end{array}$ \\
\hline \multirow{2}{*}{ 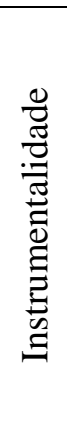 } & $\begin{array}{l}\text { 4) Você tem feito algum tipo de } \\
\text { planejamento para alcançar o } \\
\text { que deseja? }\end{array}$ & $\begin{array}{l}\text { "tenho dificuldade em fazer registros e estruturar um } \\
\text { planejamento detalhado sobre meus objetivos profissionais e } \\
\text { pessoais." } \\
\text { "planejo seguir o que me é verdadeiro, o que encanta meu } \\
\text { ser, o que impulsiona meu caminhar." }\end{array}$ \\
\hline & $\begin{array}{lr}\text { as } & \text { principais } \\
\text { você } \quad \text { tem }\end{array}$ & $\begin{array}{l}\text { "saber conciliar os períodos de lazer e família com o } \\
\text { trabalho. Chego a exaustão e prejudico minha qualidade de }\end{array}$ \\
\hline
\end{tabular}




\begin{tabular}{|c|c|c|}
\hline & $\begin{array}{l}\text { enfrentado pessoal e } \\
\text { profissionalmente para manter- } \\
\text { se motivado nessa atuação? }\end{array}$ & $\begin{array}{l}\text { vida” } \\
\text { "sou muito informal no meu trabalho e isso me atrapalha em } \\
\text { alguns momentos. Foi difícil conseguir cobrar preço dos } \\
\text { meus serviços” } \\
\text { “tenho dificuldade em dizer não para os outros. Muitas vezes } \\
\text { faço tanto o bem que me dou mal!” } \\
\text { “o mercado muitas vezes não reconhece financeiramente e } \\
\text { no tempo que eu gostaria” }\end{array}$ \\
\hline & $\begin{array}{l}\text { 6) Como você lida com as } \\
\text { dificuldades que identifica? } \\
\text { Descreva como isso tem } \\
\text { contribuído para alterar ou não o } \\
\text { seu caminho nessa atuação. }\end{array}$ & $\begin{array}{l}\text { “tenho me interessado muito mais por gestão de negócios e } \\
\text { em conhecer melhor o mercado" } \\
\text { “eu aprendo com os meus desafios. Eles são bons para o } \\
\text { crescimento. Me mantenho motivado com esse trabalho e } \\
\text { evoluo com os desafios aprendendo a trabalhar a paciência, } \\
\text { flexibilidade e a comunhão da família.” }\end{array}$ \\
\hline & $\begin{array}{l}\text { 7) Como você percebe o } \\
\text { impacto na sua vida pessoal em } \\
\text { relação à realização da sua } \\
\text { atuação? }\end{array}$ & $\begin{array}{l}\text { “estamos em uma transição de cultura. Daremos um grande } \\
\text { salto enquanto humanidade. Em momentos especiais, } \\
\text { aparecem pessoas especiais. Pretendo servir à essa mudança } \\
\text { e para isso venho me preparando interiormente.” }\end{array}$ \\
\hline & $\begin{array}{l}\text { 8) Como você compreende o } \\
\text { aumento do número de } \\
\text { profissionais que estão iniciando } \\
\text { nessa forma de atuação a } \\
\text { continuarem nesse caminho? }\end{array}$ & $\begin{array}{l}\text { “o trabalho daqueles que já estão vivendo um novo } \\
\text { paradigma é uma inspiração para os novos empreendedores. } \\
\text { A cada novo grupo que conhece novas praticas sustentáveis, } \\
\text { sempre há uma pequena parte que se compromete com a } \\
\text { sustentabilidade. Mesmo sendo pequeno esse grupo é } \\
\text { composto de pessoas que se comprometerão a vida inteira!” } \\
\text { “esse aumento de profissionais é o resultado da teoria do } \\
\text { exemplo. Percebendo que há uma coerência entre discurso e } \\
\text { pratica e que há resultados expressivos acontecendo } \\
\text { encontramos profissionais mudando de consciência em todas } \\
\text { as áreas!” }\end{array}$ \\
\hline & $\begin{array}{l}\text { 9) Em sua opinião, o que pode } \\
\text { ser encorajador para esses } \\
\text { profissionais que estão iniciando } \\
\text { essa forma de atuação a } \\
\text { continuarem nesse caminho. }\end{array}$ & $\begin{array}{l}\text { "são as diversas possibilidades de atuação. Tem muita área } \\
\text { para atuar. Se estivermos conectados com a coerência desse } \\
\text { novo paradigma, qualquer área hoje está carente de inovação } \\
\text { para uma nova visão de uma realidade mais sustentável.” }\end{array}$ \\
\hline
\end{tabular}

Quadro 1 - Trechos das entrevistas

Fonte: Dados das entrevistas 
O grupo de empreendedores selecionados para esta pesquisa compartilhou uma série de elementos importantes de sua trajetória de vida que foram fundamentais para a escolha da atuação empreendedora pela sustentabilidade. Entre os elementos trazidos, estão a busca pela vida saudável em todos os níveis, pessoal, social e ecológico; a busca por contato com diferentes culturas do mundo; o interesse pela espiritualidade do homem pós-moderno; a disciplina e a determinação por concluir projetos de interesse sejam na área acadêmica, pessoal ou profissional.

Ao iniciar o estudo da motivação, os entrevistados foram chamados a compartilhar o grau de atração do trabalho que realizam. Invariavelmente, os entrevistados declararam a integração do trabalho com a vida pessoal. Uma marca desse grupo de empreendedores é a de que o trabalho que desempenham representam a própria razão de ser e estar no mundo. Essa profunda conexão com o trabalho se dá a partir da percepção de que a vida pessoal não se separa da vida profissional. Os empreendedores desse novo paradigma declaram que empreender é reconhecer o papel social que devem desempenhar e buscar um desenvolvimento coletivo que promova a sustentabilidade da sociedade em harmonia com a natureza. Os empreendedores do novo paradigma identificam projetos pessoais integrando realizações profissionais em uma perspectiva inclusora na qual o bem estar de uma coletividade é almejada desde o núcleo familiar. A atração pelo trabalho se consolida a partir da plena integração do trabalho com a vida pessoal. Sem distinguir tempo, espaço e comportamento por diferença de ambiente, os empreendedores almejam ser o que desejam ver no mundo. Por essa confiança inerente no propósito, estabelecem como meta manter-se na própria busca, sem render-se ao velho paradigma com suas facilidades e falsas realizações.

“Acreditando-se que cada pessoa possui uma missão única e intransferível, é importante sentir que ao trabalhar cada indivíduo esteja se conectando com a sua realização maior. Trabalhar para ganhar dinheiro é um ciclo vicioso. Ao trabalhar com algo que não se realiza, o indivíduo torna mecânica a relação com o trabalho e desmotivado e não é capaz de alcançar bons resultados.”

Corroborando para essa compreensão, Joseph Campbell, grande estudioso do universo dos mitos, expressa a simbologia do Dharma indiano através da máxima "Follow your bliss!”, que em português significa siga a sua bem aventurança. O empreendedor do novo paradigma antes de tudo é um ouvinte de si mesmo, capaz de reconhecer a sua força motriz que o levará ao encontro de seu propósito no mundo, de sua auto-realização, como anunciado por Maslow. 
No campo da instrumentalidade, foi analisado o conjunto de conhecimentos que os empreendedores utilizam pra desempenha sua jornada pela sustentabilidade, mantendo-se motivados. Entre os conhecimentos abordados nessa pesquisa, o conhecimento de gestão de negócios, em especial a perspectiva de planejamento estratégico, de fato apresentou-se como uma deficiência do grupo entrevistado, uma vez em que a maioria demonstrou interesse em conhecer mais acerca do assunto, mas ignorou dominar os fundamentos e aplicações básicas inerentes à técnica administradora. Foi observado ainda, uma abordagem sutil acerca do distanciamento ideológico defendido até poucos anos em que o universo empresarial não dialogava com as questões ambientais e sociais dentro de uma perspectiva construtiva. Nesse sentido, percebeu-se que os indivíduos apresentam uma carência de conhecimento e vivências administrativas, a fim de integrar as melhores práticas de gestão em seus empreendimentos. Por outro lado, por significar uma mudança paradigmática, o surgimento desses novos empreendedores parece alavancar uma nova interpretação dos conhecimentos e práticas da administração de negócios.

No campo das expectativas, os entrevistados compartilharam a compreensão de que os resultados de suas buscas já podem ser observados no presente. O fato de associar a expectativa do trabalho ao futuro diversas vezes influencia uma busca direcionada no trabalho em vistas a alcançar uma realização que ainda está por vir. Entre os entrevistados, constatouse que a realização não está em uma meta absoluta no futuro, mas sim, em cada passo da caminhada. Nota-se que essa relação com a expectativa na motivação simboliza uma resignificação da satisfação e do papel que cada um possui na sociedade. Nesse sentido, o indivíduo já reconhece sua motivação alcançada a medida que atua em prol da sustentabilidade, e a medida que encontra seu propósito sendo trabalhado por outras mãos. O comportamento coletivo de busca por uma determinada realização permite que se compreenda melhor o papel de cada um, em uma rede cooperada, onde cada um tem consciência da sua responsabilidade, ou seja, da sua habilidade em responder ao desafio que é coletivo, nesse caso global.

O aumento do número de empreendedores comprometidos com o novo paradigma do século 21 tem ocorrido em grande parte pelo exemplo inspirador daqueles que já vivenciam essa nova realidade. Muitos empreendedores têm se sensibilizado por um novo modelo de atuação, mais cooperativo, consciente das necessidades dos ecosistemas e do impacto que suas atitudes e escolhas possuem sobre o equilíbrio da vida no planeta. O crescimento dessa rede de novos empreendedores que esta resgatando conhecimentos ancestrais e unificando as tecnologias do presente tem sido alvo de estudo de muitos pensadores contemporâneos. 
Entretanto, muito ainda há por se revelar nesse período de crises. Um grande desafio desse novo paradigma encontra-se no inesperado, no vazio fértil de possibilidades. Em diversas áreas da sociedade viveu-se um longo período de alienação da criatividade. Aqueles que desejam empreender por uma nova realidade paradigmática encontram nessa missão o desafio de criar o novo, pois não há referencias claras do que se deve reproduzir, quando o tema é sustentabilidade para um mundo novo. Em diversas áreas de atuação, profissionais estão resignificando o seu olhar, o seu papel e, consequentemente, estão inovando, empreendendo no empreendedor de si próprio. De volta ao nascimento do conceito, resgata-se a subversão do sistema como característica inerente ao ato de empreender. Repaginando o empreendedorismo no século 21, encontra-se um novo cenário de empreendedores: são profissionais que se identificam plenamente com o que realizam e acreditam no seu trabalho como a razão de ser e estar no mundo. Aliam-se uns aos outros, integrando saberes e construindo redes de conhecimento transdisciplinares. E acima de tudo, são capazes de ouvir o que lhes é chamado a realizar, permitindo que os futuros projetos sejam decorrência de uma caminhada anterior, tão importante quanto a realização concreta de suas atividades. Vivem o processo, confiantes de que os resultados virão a partir de um tomada de consciência planetária que já está em curso.

Tecendo uma análise mais aprofundada a respeito dos setores de atuação dos empreendedores e o comportamento motivacional atrelado ao indivíduo, observou-se os seguintes resultados:

- Não foi apresentada diferenciação determinante entre o grau de motivação dos indivíduos do primeiro, segundo e terceiro setor. Observou-se que a motivação elevada não se caracterizou pelo setor de atuação em si, mas pela relação do indivíduo com o trabalho que desempenha.

- Os empreendedores dos três setores da sociedade apresentam uma forte identificação com o papel que desempenham e acreditam vivenciar os valores que desejam para um mundo mais sustentável. Essa forte relação com o trabalho pela sustentabilidade possibilita maior flexibilidade entre os diferentes ambientes de trabalho. Entretanto, para os empreendedores do terceiro setor e profissionais autônomos, quando questionados sobre a possibilidade de trabalharem em um órgão público a resposta foi negativa, por acreditarem não terem o perfil de um cargo público.

- Quanto à relação com o trabalho, constatou-se que os empreendedores do terceiro setor e profissionais autônomos apresentam maior desgaste motivacional que os demais. 
- Não se apresentou correlação direta quanto à trajetória de vida dos entrevistados e a escolha em que setor da sociedade atuam. A partir desse estudo recomenda-se uma pesquisa mais aprofundada para identificar possíveis correlações.

- Observou-se que os membros do primeiro e segundo setor se identificam mais facilmente com o papel de empreendedores que os do terceiro setor. Infere-se que o conceito de empreendedor ainda não é compreendido por muitos profissionais que atuam pela sustentabilidade. Observou-se que o conceito de empreendedor muitas vezes é compreendido apenas pela abordagem econômica o que provocou um afastamento de muitos indivíduos do conhecimento de gestão e negócios.

- Notou-se que razão pela qual os entrevistados reconhecem em si uma atuação empreendedora é a busca por uma nova forma de viver no mundo que condiza com os ideais que os regem. Dessa forma percebeu-se entre as características empreendedoras mais citadas, a disciplina, a ética, a visão de oportunidades. 


\title{
5 CONCLUSÕES E RECOMEDAÇÕES
}

\begin{abstract}
"Eis a finalidade primordial da economia e das organizações: assegurar uma ordem social que permita o maior grau de bem-estar para a comunidade.” (AKTOUF, 2004)

“O ser humano em si representa uma promessa, um potencial pleno de possibilidades. Os antigos afirmavam que o ser humano ainda não nasceu. Diz-se que enquanto humanidade somos apenas uma possibilidade, um potencial florescimento. Um futuro vir a ser.” (CREMA, 2001)
\end{abstract}

Uma nova humanidade está nascendo. Esse momento planetário é caracterizado por um profundo período de mudança paradigmática. A humanidade vive a gestação de uma nova realidade, que busca a saúde e a plenitude da vida na Terra. O processo de transformação veio se intensificando lenta e gradativamente, por meio do despertar da consciência interior dos seres humanos em todos os povos da Terra. O mundo deseja a paz, a harmonia entre os seres da Natureza, a abundância de saúde, alimentos e da criatividade da expressão humana. O século 21 iniciou um diálogo não apenas entre os países exportadores de tecnologia, os consumidores de petróleo ou os neo-colonizadores de recursos naturais. O século 21, muito antes de deflagrar as macro relações internacionais, iniciou uma reflexão profunda dos seres humanos. Embora grande parte da população se sinta inerte em um velho paradigma de consumo, exploração e crescimento econômico-industrial a qualquer preço, muitas são as novas configurações de relacionamento cidadão-sociedade que em todo o mundo têm se buscado como base na ética da sustentabilidade.

Esse estudo comprovou que o empreendedor do novo paradigma é uma liderança de uma nova configuração social. Aktouf (2004), ao citar Aristóteles em que o homem é um “Zoon politikon”, ou seja, um animal político, feito para viver em estado de comunidade, afirma que o homem carrega consigo valores comunitários como a solidariedade, o sentimento de pertencimento e a responsabilidade para com a comunidade. Com base nessa reflexão observa-se o verdadeiro papel das organizações na sociedade e o verdadeiro papel dos empreendedores e lideranças da sociedade. Um autêntico líder é, sobretudo, uma pessoa que se conheceu e se conquistou, aprendendo a liderar a si mesmo.

A humanidade adentrou à Era da emancipação humana. Os seres desejosos de poder e dominação sobre os demais não mais ocupam o papel central da sociedade. Uma nova configuração circular, e descentralizada está orientando a sociedade pós-moderna a reconhecer no indivíduo um cidadão com plenos direitos e também deveres humanos. Muito 
se falou no século 20 a respeito dos Direitos Humanos, com a chegada do século 21, se apresentam agora os Deveres Contemporâneos. Deveres que se aplicam a todos os cidadãos e cidadãs, a todas as empresas e organizações. Deveres contemporâneos por uma possível e única sobrevivência da humanidade. O século 21 apresenta-se assim, convocando o amadurecimento da humanidade, que passa a reconhecer-se parte de um todo, parte de um sistema vivo que é o planeta e que já apresenta seus sinais de desequilíbrio. Nesse momento planetário, vive-se o nascimento de uma nova humanidade. Observa-se por todo o planeta o nascimento de uma consciência sustentável que se apresenta pela permacultura como "seja responsável pela sua própria existência!”. Um novo paradigma está sendo construído resignificando as relações, substituindo atitudes e transformando as escolhas diárias da população, por produtos ecológicos, por responsabilidade social, por nova educação ambiental, por um novo papel das empresas na sociedade. A globalização do século 21 globaliza os seres humanos pela consciência da sustentabilidade e não pela limitada promessa de abertura de mercados.

Esse estudo apresentou como estamos gestando um novo paradigma do empreendedorismo. Empreender, segundo os franceses do século XV, no sentido radical de transgredir a ordem vigente. É possível perceber que a humanidade está sentindo as dores de uma gestação planetária por um novo sentido de ser e estar no mundo. Dores físicas, emocionais e espirituais. A natureza anuncia as transformações climáticas, as cidades anunciam a insustentável organização das classes sociais num sistema explorador e competitivo que alimenta a pobreza e a violência, e alma dos homens clama por uma consciência espiritual que promova a cultura de paz e não a justificativa das guerras santas.

Para compreender o nascente paradigma é preciso reconhecer que a atual política econômica, empresarial e social não é, em termos gerais, coerente com o desenvolvimento global viável de longo prazo. É chegada a hora em que a era industrial do Ocidente, as crenças convencionais do método científico, a insaciável sede pelo progresso material, e a cultura da satisfação à curto prazo não mais correspondem aos anseios humanos.

O novo ser do século 21 empreenderá a mudança de paradigma que já se encontra em curso. Esses empreendedores movidos a desafios encontram na sabedoria de Gonçalves Dias, a lição do guerreiro tupi, I Juca Pirama "os desafios que aos fracos abate, aos fortes, aos bravos, só pode exaltar!”. O empreendedorismo é um conceito dinâmico, e o empreendedor destaca-se ou mesmo surge quando novas situações aparecem, novas decisões são tomadas, novos rumos são escolhidos. Empreendedor hoje é aquele que compreende as condições 
adversas do caminho insustentável explorado pelo homem nos últimos séculos. Empreendedor hoje é aquele capaz de integrar razão e emoção, mente e espírito e colocar seu talento e suas competências a serviço da sustentabilidade. Empreendedor hoje é aquele que compreende o lucro não como fim de uma organização, mas como meio, para se promover a sustentabilidade da rede da qual pertence.

Essa pesquisa teve como objetivo anunciar o campo vasto do novo paradigma do século 21 por meio dos protagonistas dessa transição, os empreendedores da sustentabilidade. Essa investigação contribuiu para os estudos de motivação e empreendedorismo sustentável, em especial. E é principalmente um convite transdisciplinar aos novos atores sociais que desejam empreender pela sustentabilidade. Buscou-se nessa pesquisa revelar os aspectos da motivação do grupo entrevistado que apresenta uma riqueza vivencial a ser compartilhado com os demais atores da transição pela sustentabilidade na sociedade.

Por restrições de tempo, esse estudo concentrou esforços em um grupo de empreendedores que vem se destacando na comunidade de Brasília com sua atuação pela sustentabilidade. Recomenda-se que estudos posteriores avancem a partir dessa pesquisa, aprofundando na analise da motivação e demais características inerentes a esse novo ator social que está surgindo.

Esta pesquisa concluiu que há uma carência de pesquisas que integrem os estudos de motivação e o universo de empreendedores que promovem o alcance da sustentabilidade. Destaca-se ainda, a carência de conhecimento e experiência em gestão de negócios existente entre esses empreendedores, orientando-se para uma necessária integração entre o campo socioambiental e o campo empreendedor. Infere-se por meio desta pesquisa que o aumento da atuação mais consciente em relação ao meio ambiente e a sociedade é uma tendência dos empreendedores do Século 21, protagonistas de um novo paradigma onde a visão de futuro e a consciência socioambiental superam a busca pelo lucro e desenvolvimento econômico, promovendo a cidadania no mundo em primeiro plano. 


\section{REFERÊNCIAS}

AKTOUF, O. Pós-Globalização, administração e racionalidade econômica: a síndrome do avestruz. São Paulo: Atlas, 2004.

ASHLEY, P., A. et al. Ética e responsabilidade social nos negócios. São Paulo: Saraiva, 2003.

BORGES-ANDRADE, J.; ZANELLI, J. C.; BASTOS, A. V. B. Psicologia, organizações e trabalho no Brasil. $1^{\text {a }}$ ed. Porto Alegre: Artmed, 2004.

CAPRA, F. O Ponto de Mutação: a ciência, a sociedade e a cultura emergente. 25 ed. São Paulo: Cultrix, 1982.

CHIAVENATO, Idalberto. Recursos humanos: ed. compacta,7 ed. São Paulo: Atlas, 2002.

CORREA. D. F. O empreendedorismo sustentável como fator primordial para a sobrevivência e prosperidade organizacional: um estudo de caso sobre a empresa Goóc. Dissertação - Centro Universitário Metropolitano de São Paulo. São Paulo, 2008

CREMA, R.; ARAÚJO, W. Liderança em tempo de transformação. Brasília: Letrativa. 2001.

Saúde e Plenitude: um caminho para o ser. 2. ed. São Paulo: Summus, 1995.

ELENA, J.; ORRICO, J.; HADDAD. J. A Comunicação na mudança de hábitos e valores. Dissertação (Publicidade e Propaganda). Universidade de Brasília, Brasília, 2008.

GARCIA, C.; ZANCANARO, F.; CALDATO, S.; TONIAL, T.; CANOPF, L. Responsabilidade social empresarial no Brasil. Synergismus scyentifica UTFPR, Pato Branco, $01(1,2,3,4)$ : 1-778. 2006.

GOIS, J. B. H.; SANTOS, A. O.; COSTA, I. S. Responsabilidade social empresarial e solidariedade: uma análise dos discursos dos seus autores. Serviço Social \& Sociedade. Ano XXV, n.78, p. 82-110, jul. 2004. 
GOMES, B. Análise das ações socioambientais em empresas do setor de telecomunicações e a percepção de seus consumidores. Dissertação (Administração de Empresas) - Universidade de Brasília, Brasília, 2008.

Habermas, J. Conhecimento e interesse. Rio de Janeiro: Guanabara, 1987

Harman, W. Uma total mudança da realidade. 1ed. São Paulo: Pensamento, 1994.

INSTITUTO AKATU. Consumo Consciente. 2008. Disponível em:

<http://www.akatu.org.br/consumo_consciente/oque>. Acesso em: 13 nov. 2009.

IPEA - Instituto de Pesquisa Econômica aplicada. Cresce a responsabilidade social, 2006.

MARKET ANALYSIS. Monitor responsabilidade Social Corporativa 2009. Disponível em: < http://www.marketanalysis.com.br/mab/produtos/RSC2009.pdf $>$. Acesso em: 8 nov. 2009.

MELO, F. P. FROES, C. Responsabilidade social e cidadania empresarial: administração do terceiro setor. Rio de Janeiro: Qualitymark, 1999.

NETO, F.; BRENNAND,J. Empresas socialmente sustentáveis: o novo desafio da gestão moderna. Rio de Janeiro: Qualitymark, 2004.

OLIVEIRA, J. A. Responsabilidade social em pequenas e médias empresas. Revista de Administração de Empresas. v. 24, n. 4, 1984.

PARIS. Painel intergovernamental sobre mudança do clima. Mudança do Clima 2007: a Base das Ciências Físicas. Fev. 2007

RINZLER, R.; RAY, M. O novo paradigma nos negócios. São Paulo: Cultrix, 1993

RODRIGUES, C. Teorias de motivação. teorias de processo. Instituto Politécnico de Coibra. Portugal, jun., 2006.

SCHUMPETER, J. Teoria do desenvolvimento econômico. São Paulo: Nova Cultural, 1982.

WEIL, P. A Arte de Viver em Paz. UNESCO. 2002.

TADIN, A. P. O conceito de motivação na teoria das relações humanas. Maringa Management Revista de Ciências Empresariais, Maringá, v.2, n.1, p.40 - 47 jan./jun. 2005.

TRIGUEIRO, A. Mundo sustentável: abrindo espaço na mídia para um planeta em 
transformação. 2 ed. São Paulo: Globo, 2005.

VROOM, V.H. Work and motivation. San Francisco: Jossey- Bass, 1995. 


\section{APÊNDICE}

\section{Apêndice A - Roteiro da Entrevista}

\section{Introdução Pessoal e Atuação}

Objetivo: contextualização das vivências do indivíduo e histórico da atuação.

1. Apresente brevemente a sua trajetória profissional.

2. Que elementos da sua trajetória contribuíram para sua escolha profissional?

\section{Valência}

Objetivo: Identificar o Grau de Atração do indivíduo para o trabalho que desenvolve.

3. Quanto você valoriza sua atuação profissional na sua vida?

4. E Por que você valoriza isso?

5. Como isso atraiu você inicialmente? E hoje como isso atrai você?

6. O que você espera realizar com essa atuação profissionalmente e pessoalmente?

\section{Instrumentalidade}

Objetivo: Identificar o Grau de Consciência do Caminho a percorrer para manter a motivação.

7. Você tem feito algum planejamento pessoal ou profissional para alcançar o que deseja?

8. Quais as dificuldades/desafios você tem enfrentado pessoal e profissionalmente?

9. Como você lida com as dificuldades que identifica? Descreva como isso tem contribuído para alterar ou não o seu caminho nessa atuação.

\section{Expectativa}

Objetivo: Identificar que conseqüências estão associadas ao desejo de recompensa.

10. Como você percebe o impacto na sua vida pessoal quanto ao alcance do que você realiza / espera realizar? E o impacto na sociedade?

11. Como você compreende o aumento do número de profissionais que tem se assemelhado à sua forma de atuação? O que tem gerado isso, em sua opinião?

12. Em sua opinião, o que pode ser encorajador para esses profissionais que estão iniciando essa forma de atuação a continuarem nesse caminho? 